III) Nordisk

Ministerråd

\title{
Mismatchproblemer i Norden
}

En kortlægning af rekrutteringssituationen i nordiske væksterhverv

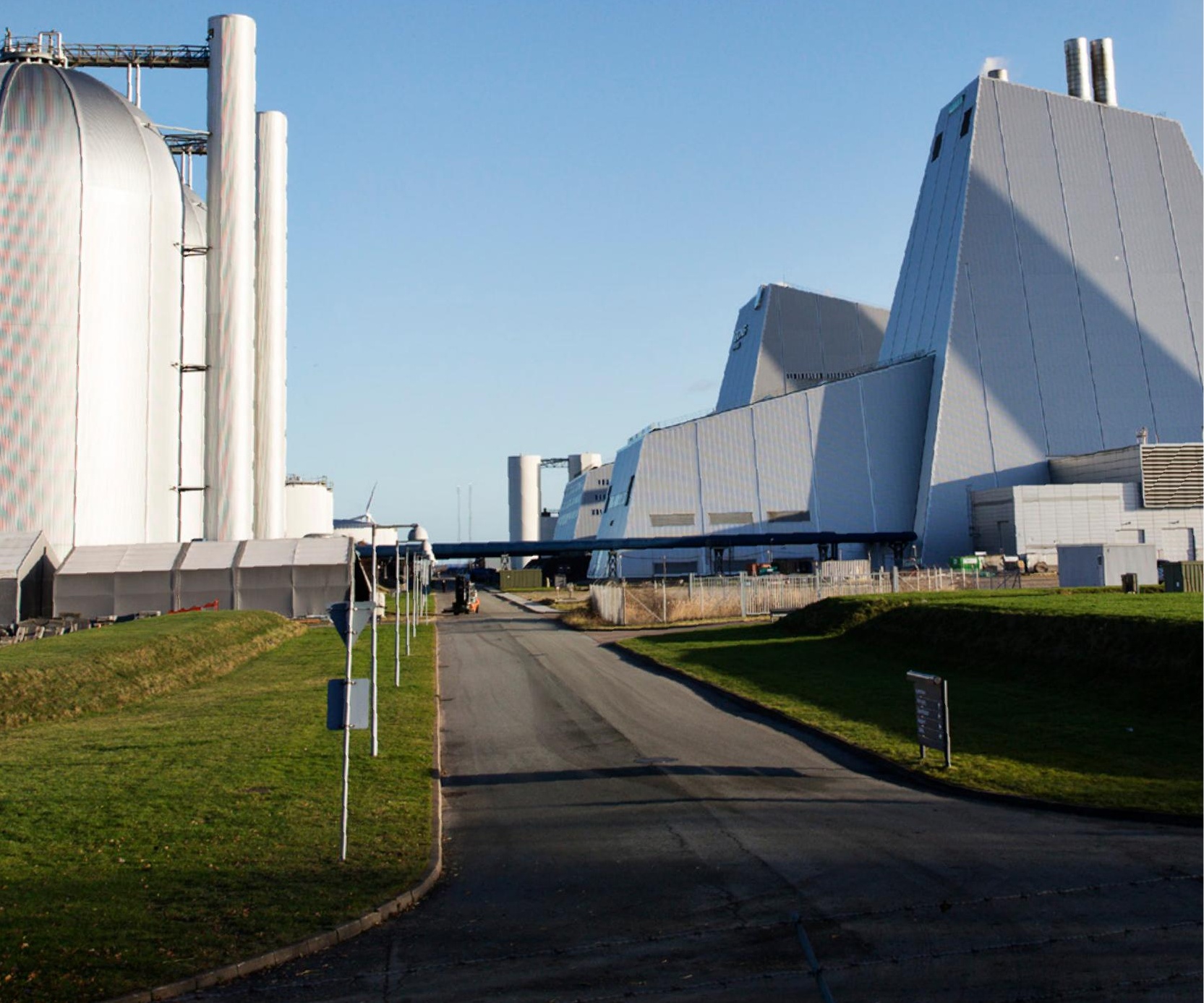





\section{Mismatchproblemer i Norden}

En kortlægning af rekrutteringssituationen i nordiske væksterhverv

Andreas Højbjerre

Rasmus Mikkelsen

TemaNord 2017:515 


\section{Mismatchproblemer i Norden}

En kortlægning af rekrutteringssituationen i nordiske væksterhverv

Andreas Højbjerre

Rasmus Mikkelsen

ISBN 978-92-893-4908-6 (PRINT)

ISBN 978-92-893-4909-3 (PDF)

ISBN 978-92-893-4910-9 (EPUB)

http://dx.doi.org/10.6027/TN2017-515

TemaNord 2017:515

ISSN 0908-6692

Standard: PDF/UA-1

ISO 14289-1

(c) Nordisk Ministerråd 2017

Layout: NMR

Omslagsfoto: Ty Stange

Tryk: Rosendahls

Printed in Denmark

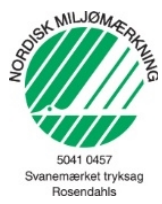

Denne rapport er udgivet med finansiel støtte fra Nordisk Ministerråd. Indholdet i rapporten afspejler dog ikke nødvendigvis Nordisk Ministerråds synspunkter, meninger, holdninger eller anbefalinger.

\section{Det nordiske samarbejde}

Det nordiske samarbejde er en af verdens mest omfattende regionale samarbejdsformer. Samarbejdet omfatter Danmark, Finland, Island, Norge og Sverige samt Færøerne, Grønland og Åland.

Det nordiske samarbejde er både politisk, økonomisk og kulturelt forankret, og er en vigtig medspiller i det europæiske og internationale samarbejde. Det nordiske fællesskab arbejder for et stærkt Norden i et stærkt Europa.

Det nordiske samarbejde ønsker at styrke nordiske og regionale interesser og værdier i en global omverden. Fælles værdier landene imellem er med til at styrke Nordens position som en af verdens mest innovative og konkurrencedygtige regioner. 


\section{Indhold}

Forord t.1-1-1-1

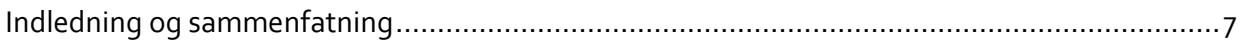

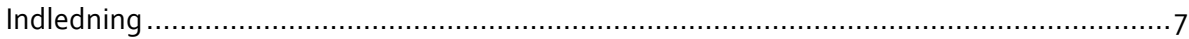

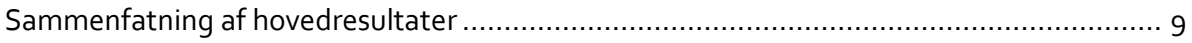

1. Udvælgelse af væksterhverv, metode og datagrundlag ................................................15

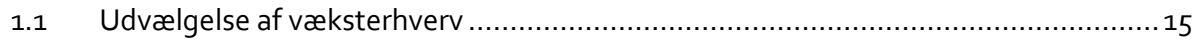

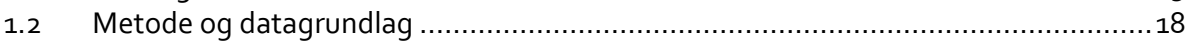

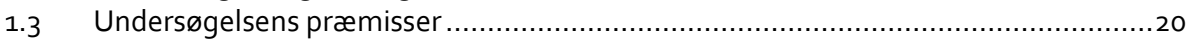

2. Omfang og konsekvens af rekrutteringsudfordringer.................................................. 23

2.1 Omfanget af rekrutteringsudfordringer i nordiske væksterhverv .................................23

2.2 Omfanget af rekrutteringsudfordringer i de enkelte lande ……...........................25

2.3 De seneste tre års udvikling i rekrutteringsudfordringer .....................................26

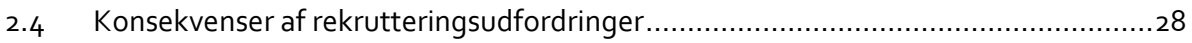

3. Årsager til rekrutteringsudfordringer og vurdering af uddannelser ..................................33

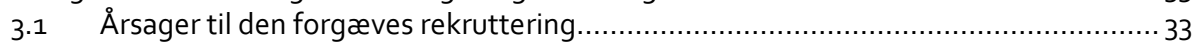

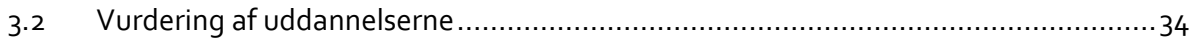

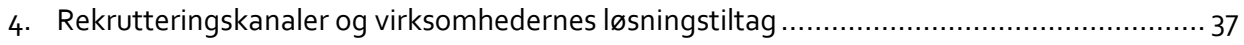

4.1 Virksomhedernes brug af rekrutteringskanaler ……............................................... 37

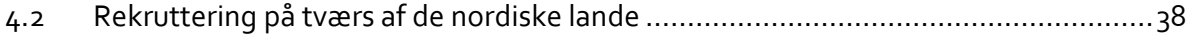

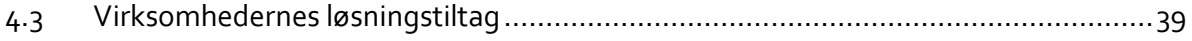

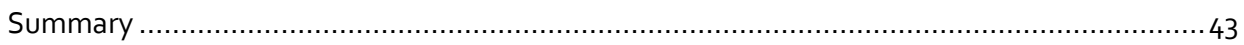

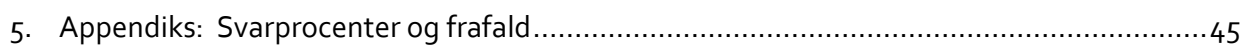





\section{Forord}

Som led $\mathrm{i}$ arbejdet med at levere evidensbaseret viden om arbejdsmarkederne i Norden har Nordisk Ministerråds Arbejdsmarkedsudvalg bedt Højbjerre Braver Schultz om at gennemføre en undersøgelse af rekrutteringsudfordringer i nordiske væksterhverv.

Der er ikke tidligere foretaget systematiske undersøgelser af rekrutteringssituationen på tværs af de nordiske landes væksterhverv, og denne undersøgelse bidrager således med ny viden herom. Derudover er rapporten det først forsøg på at skabe et nyt systematisk indsamlet datagrundlag for arbejdskraftefterspørgslen baseret på statistisk tekstanalyse af jobopslag i Sverige, Danmark og Norge.

Rapporten er primært udarbejdet i efteråret 2016. 



\section{Indledning og sammenfatning}

\section{Indledning}

For at sikre fortsat vækst i Norden er det centralt, at virksomheder kan få de kompetencer, som de efterspørger. Det er derfor vigtigt at opbygge viden om, hvorvidt virksomheders efterspørgsel efter arbejdskraft er tilstrækkeligt dækket af arbejdskraftudbuddet, og om der er mismatchproblemer på de nordiske arbejdsmarkeder.

Modvirkning af mismatchproblemer på arbejdsmarkedet er et centralt element i tilrettelæggelse af en beskæftigelses- og uddannelsespolitik, som understøtter økonomisk vækst. Mismatchproblemer kan have økonomiske konsekvenser for både individer, virksomheder og de offentlige finanser. Samfundsøkonomien påvirkes gennem flere kanaler. Et bedre jobmatch kan således betyde lavere strukturel ledighed, højere løn og i sidste ende større skatteindtægter. Samtidig kan et bedre og hurtigere jobmatch øge produktionen.

Formålet med denne undersøgelse er kortlægge de aktuelle forskelle og ligheder $\mathrm{i}$ rekrutteringsudfordringerne i en række væksterhverv i Sverige, Danmark og Norge. Blandt de hovedspørgsmål, som rapporten forsøger at besvare, er spørgsmålene, om virksomheder kan få den nødvendige arbejdskraft, hvad konsekvenserne er af eventuelle rekrutteringsudfordringer, og hvordan virksomhederne forsøger at løse disse udfordringer.

Rapporten fokuserer på fem udvalgte væksterhverv, jf. boks 1. Det er erhverv, hvor nordiske virksomheder traditionelt har klaret sig godt i den globale konkurrence. Erhvervene er blandt andet kendetegnet ved at være specialiserede, have en nordisk styrkeposition og en relativt høj eksportandel. Det er samtidig erhverv, som i høj grad afhænger af kvalificeret arbejdskraft. Resultaterne i rapporten baserer sig på en spørgeskemaundersøgelse, hvor der er indsamlet 1.723 svar fra virksomheder i Sverige, Danmark og Norge.

I rapporten anvendes for første gang en statistisk analyse af online jobopslag til at udpege virksomheder, der har forsøgt at rekruttere arbejdskraft inden for de udvalgte væksterhverv. 


\section{Boks. 1. Beskrivelse af de udvalgte væksterhverv}

\section{Informations- og Kommunikationsteknologi (IKT)}

IKT omfatter udvikling og produktion af teknologier til digital styring og behandling af informationer. Det vil især omfatte digital indsamling, lagring, behandling, overførelse og præsentation af information. Erhvervet omfatter ikke kun virksomheder, der direkte udvikler $\mathrm{fx}$ software eller hardware (selve IT-sektoren), men også virksomheder i en lang række andre brancher, hvor der bruges IT til enten produktion eller styring af ressourcer.

\section{Digital og automatiseret produktion}

Industrien og fremstillingserhvervet er et centralt erhverv i Norden, ikke mindst som følge af en løbende digitalisering og automatisering af erhvervet. Erhvervet har på tværs af de nordiske lande haft en relativ høj produktivitetsvækst i forhold til resten af landenes økonomier. Erhvervet ændres i disse år som følge af nye digitale produktionsteknogier og løbende automatisering af produktionen.

\section{Kreative erhverv og design}

Kreative erhverv og design dækker over en lang række forskellige erhverv inden for områderne arkitektur, design, mode, møbeldesign samt reklame. Erhvervet omfatter både produktions- og servicevirksomheder. Erhvervet har internationalt set været i betydelig vækst i det seneste årti, blandt andet som følge af øget global velstand og nye informations- og kommunikationsteknologier.

\section{Grøn teknologi}

Dette erhverv dækker over brugen af forskellige miljøvidenskaber til at begrænse menneskenes indflydelse på miljø og ressourcer. Områder omfatter blandt andet vedvarende energi, genbrug og udvikling af energieffektive produkter og $\mathrm{fx}$ digitale redskaber til energibesparing eller miljøforbedringer.

\section{Life Science}

Dette erhverv omfatter de delvist overlappende arbejdsmarkeder inden for medico-, bioteknologi-, pharma- og fødevareområdet. Det vil sige, at Life Science blandt andet omfatter arbejdet med at anvende biologiske systemer i fx fødevare- og medicinalindustrien og virksomheder, der udvikler, producerer og sælger medicinsk udstyr. 


\section{Sammenfatning af hovedresultater}

Undersøgelsen giver en række nye indsigter i omfanget af rekrutteringsudfordringer i Norden, og hvordan virksomhederne i praksis forsøger at overkomme disse udfordringer.

Overordnet peger undersøgelsen på, at rekrutteringsudfordringer og mismatch mellem udbud og efterspørgsel på arbejdsmarkedet er en reel økonomisk vækstbarriere i de fem væksterhverv i Norden. Mangel på arbejdskraft har konsekvenser for virksomhederne af flere grunde. Dels peger undersøgelsen på, at det er en produktionsbegrænsning, fordi virksomhederne i mange tilfælde må udskyde aktiviteter, dels at det kan betyde lavere produktivitet, da virksomhederne er nødsaget til at ansætte medarbejdere, som ikke udgør deres kompetencemæssige førstevalg.

Undersøgelsen viser, at rekrutteringsudfordringerne på tværs af de tre lande er størst inden for erhvervene IKT og Digital og automatiseret produktion, hvor op mod hver tredje rekrutteringsforsøg er forgæves. Her er både rekrutteringsudfordringerne og de afledte produktionsbegrænsninger størst.

Undersøgelsen peger desuden på, at rekrutteringsudfordringerne både skyldes mismatch, i forhold til hvor stort arbejdsudbuddet er (volumenmæssigt mismatch), og at udbuddet ikke altid har de rette kompetencer (indholdsmæssigt mismatch). Virksomhederne har en række løsningstiltag til at overkomme disse rekrutteringsudfordringer, hvoraf øget international rekruttering, herunder i Norden, og outsourcing er centrale elementer.

I det følgende fremhæves en række af undersøgelsens konklusioner, som følger de tre hovedafsnit i rapporten:

- Omfang og konsekvens af rekrutteringsudfordringer.

- Årsager til rekrutteringsudfordringer og vurdering af uddannelser.

- Rekrutteringskanaler og virksomhedernes løsningstiltag. 


\section{Omfang og konsekvens af rekrutteringsudfordringerne}

De største rekrutteringsudfordringer ses inden for IKT og Digital og automatiseret produktion

Der er betydelige rekrutteringsudfordringer inden for væksterhvervene i Sverige, Danmark og Norge. Godt hver fjerde rekrutteringsforsøg er forgæves, hvilket dækker over, at stillingen ikke er blevet besat eller er besat af en medarbejder, som ikke fuldt ud dækker behovet.

De største rekrutteringsudfordringer på tværs af de tre lande er inden for $I K T$, hvor knap hver tredje rekrutteringsforsøg er forgæves. Rekrutteringsudfordringerne tyder også på betydelige rekrutteringsudfordringer inden for Digital og automatiseret produktion. Rekrutteringsudfordringerne er derimod mindst inden for væksterhvervet Life Science, hvor ca. knapt hver ottende rekrutteringsforsøg er forgæves.

Det er de samme væksterhverv, som har de største rekrutteringsudfordringer i de tre lande. Undersøgelsen peger dog på, at der er relativt store rekrutteringsudfordringer inden for Kreative erhverv og design i Danmark, mens dette billede ikke kan genfindes i Sverige og Norge.

Rekrutteringsudfordringerne findes på tværs af uddannelsesniveauer. Således er der i de enkelte væksterhverv forgæves rekrutteringer både blandt virksomheder, som leder efter medarbejdere med lange uddannelser, og virksomheder, som leder efter medarbejdere med kortere uddannelser. Eksempelvis er det inden for IKT næsten hver tredje rekrutteringsforsøg, som er forgæves for både lange, mellemlange og korte videregående uddannelser.

\section{På tværs af væksterhverv er rekrutteringsudfordringerne størst i Sverige og mindst i Norge}

Med undtagelse af Kreative erhverv og design er rekrutteringsudfordringerne størst i Sverige inden for alle erhverv. I Sverige er det således omkring $29 \%$ af rekrutteringsforsøgene (i gennemsnit på tværs af væksterhverv), som er forgæves. Til sammenligning er tallet $25 \%$ for Danmark og $19 \%$ for Norge. Forskellene kan både dække over forskelle i den overordnede konjunktursituation i de enkelte lande og over mere strukturelle forskelle i matchet mellem udbud og efterspørgsel. 


\section{Rekrutteringsudfordringerne har reelle konsekvenser}

Rekrutteringsudfordringerne har en række økonomiske konsekvenser for virksomheder. I gennemsnit svarer $36 \%$ af virksomhederne, at rekrutterings-udfordringer har medført, at de har udskudt eller helt droppet aktiviteter. Der er samtidig en tendens til, at denne andel er særlig høj i væksterhverv, hvor rekrutteringsudfordringerne er størst.

Rekrutteringsudfordringer har derudover ført til, at ca. hver tredje virksomhed enten har opgivet at rekruttere eller har ansat en medarbejder med en anden profil end tiltænkt. Undersøgelsen viser, at rekrutteringsudfordringerne ofte også medfører produktionsbegrænsninger, selv om stillingen i sidste ende bliver besat, $\mathrm{fx}$ med en anden profil end tiltænkt.

\section{Årsager til rekrutteringsudfordringer og vurdering af uddannelserne}

\section{Rekrutteringsudfordringer skyldes både mismatch i indhold og i volumen}

Omkring halvdelen af de virksomheder, der har oplevet forgæves rekrutteringer, peger på, at den væsentligste årsag til den forgæves rekruttering er manglende tekniske kompetencer hos ansøgerne. Derudover angiver virksomhederne, at manglende erfaring blandt ansøgerne også er en væsentlig årsag. En del af rekrutteringsudfordringerne skyldes således et indholdsmæssigt mismatch mellem virksomheders efterspørgsel og udbuddet af kompetencer.

Omkring hver tredje virksomhed peger på, at udfordringerne skyldes manglende ansøgere eller mangel på formel uddannelse hos ansøgerne. Dette indikerer, at rekrutteringsudfordringerne også hænger sammen med et volumenmæssigt mismatch mellem udbud og efterspørgsel af arbejdskraft.

Godt 4 ud af 10 virksomheder vurderer, at deres kompetencebehov dækkes af uddannelserne

På tværs af lande og væksterhverv svarer mere end $44 \%$ af virksomhederne, at uddannelserne dækker deres respektive kompetencebehov i meget høj eller høj grad. Kun en mindre andel af virksomhederne svarer, at uddannelserne slet ikke dækker deres behov.

Virksomheder, som har oplevet en forgæves rekruttering, vurderer, at uddannelserne i mindre grad dækker deres kompetencebehov. Det indikerer, at virksomheder- 
nes rekrutteringsudfordringer kan skyldes, at de kompetencer, man opnår på uddannelserne, ikke har et højt nok niveau, og/eller at uddannelserne ikke giver de studerende de kompetencer, som virksomhederne efterspørger.

\section{Uddannelser inden for Digital og automatiseret produktion dækker} kompetencebehovet dårligst

Undersøgelsen peger på, at virksomhedernes kompetencebehov inden for Digitale og automatiseret produktion dækkes dårligst af uddannelserne på tværs af de tre lande. Her vurderer kun omkring halvdelen af virksomhederne, at deres behov helt eller i høj grad dækkes af de relevante uddannelser. Til sammenligning dækkes kompetencebehovet for 8 ud af 10 virksomheder inden for Life Science.

\section{Rekrutteringskanaler og virksomhedernes løsningstiltag}

\section{Virksomhederne bruger en bred vifte af rekrutteringskanaler}

De mest udbredte rekrutteringskanaler er online jobopslag, som bruges af 7 ud af 10 virksomheder. Annoncering på egen hjemmeside bruges af 6 ud af 10 virksomheder, mens annoncering via de sociale medier anvendes af $5 \mathrm{ud}$ af 10 virksomheder. Der er kun 1 ud af 10 virksomheder, som anvender arbejdsløshedskasser, offentlige jobformidlinger eller lignende.

\section{Omkring hver fjerde virksomhed rekrutterer nordisk}

Omkring en fjerdedel af virksomhederne forsøger i hovedreglen eller nogle gange at rekruttere i de andre nordiske lande. Virksomheder i Norge forsøger oftere at rekruttere i andre nordiske lande end virksomheder i Sverige og Danmark. I Norge er det godt $40 \%$ af virksomhederne, som i hovedregel eller nogle gange forsøger at rekruttere i andre nordiske lande. Denne andel er omkring dobbelt så høj som i Sverige og Danmark. Undersøgelsen viser desuden, at sprog og familiemæssige overvejelser er de største barrierer for at rekruttere fra andre nordiske lande.

\section{Rekrutteringsudfordringer fører til bredere brug af rekrutteringskanaler}

Omkring hver fjerde virksomhed, som oplever rekrutteringsudfordringer, benytter sig af bredere rekrutteringskanaler for at løse sine rekrutteringsudfordringer. 
Der er mindre forskelle på, hvordan virksomhederne i de enkelte væksterhverv forsøger at løse deres rekrutteringsudfordringer. Der er således en tendens til, at virksomheder inden for Life Science og Kreative erhverv og design oftere end andre virksomheder forsøger at rekruttere internationalt, når de har rekrutteringsudfordringer. Virksomheder inden for IKT gør lidt oftere brug af bredere rekrutteringskanaler ( $\mathrm{fx}$ brug af rekrutteringsfirmaer) end virksomheder inden for de andre væksterhverv, mens virksomheder inden for Digital og automatiseret produktion i højere grad benytter intern opkvalificering (efteruddannelse).

\section{Rekrutteringsudfordringer presser virksomheder til internationalisering}

Omtrent hver tiende virksomheder benytter rekruttering i et andet nordisk land for at løse på sine rekrutteringsudfordringer. Denne tendens er særlig udtalt blandt virksomheder inden for Grøn teknologi, hvor rekrutteringsudfordringer får op mod en tredjedel af virksomhederne til at orientere sig mod et bredere nordisk arbejdsmarked.

\section{Rekrutteringsudfordringer betyder også øget outsourcing}

Outsourcing bruges også som løsningsstrategi i forhold til at imødegå rekrutteringsudfordringer, men i mindre grand end international rekruttering. Inden for IKT angiver 18 $\%$ af virksomhederne, at de bruger outsourcing af opgaver (indenlandsk og udenlandsk) som en løsningsstrategi. Dette er væsentligt mere end inden for blandt andet Digital produktion og automatisering, hvor andelen kun er ca. $6 \%$ 



\section{Udvælgelse af væksterhverv, metode og datagrundlag}

\section{$1.1 \quad$ Udvælgelse af væksterhverv}

I undersøgelsen fokuseres på fem udvalgte væksterhverv. Væksterhverv er ikke et veldefineret begreb, men det er ikke et selvstændigt formål med denne undersøgelse at afgrænse begrebet væksterhverv. Flere rapporter har tidligere beskæftiget sig med dette tema, og udvælgelsen af de fem væksterhverv i denne undersøgelse baserer sig blandt andet på dette arbejde. De fem udvalgte væksterhverv i denne undersøgelse er:

- Informations- og kommunikationsteknologi(IKT).

- Digital og automatiseret produktion.

- Kreative erhverv og design.

- Grøn teknologi.

- Life Science.

Fælles for disse erhverv er, at det er nordiske erhverv, som traditionelt har klaret sig godt i den globale konkurrence. Erhvervene er blandt andet kendetegnet ved at være specialiserede, have en nordisk styrkeposition og en relativ høj eksportandel. Det er samtidig erhverv, som i høj grad afhænger af kvalificeret arbejdskraft, og hvor der er et potentiale ved øget tværnordisk mobilitet og integration af arbejdsmarkederne. De enkelte væksterhverv er nærmere beskrevet nedenfor. 
Informations- og kommunikationsteknologi (IKT)

Informations- og kommunikationsteknologi, IKT, omfatter udvikling og produktion af teknologier til digital styring og behandling af informationer. Det omfatter især digital indsamling, lagring, behandling, overførsel og præsentation af information. Erhvervet omfatter ikke kun virksomheder, der direkte udvikler fx software eller hardware (selve IT-sektoren), men også virksomheder i en lang række andre brancher, hvor der bruges IT til enten produktion eller styring af ressourcer. For eksempel er finansielle virksomheder meget IKT-intensive.

IKT-erhvervet er et internationalt væksterhverv, som blandt andet er drevet af en løbende digitalisering af en lang række arbejdsområder. Virksomheder i Norden har en styrkeposition inden for området på grund af en stærk IT-sektor og generelt gode ITfærdigheder i arbejdsstyrken. ${ }^{1}$

\section{Digital og automatiseret produktion}

Digital og automatiseret produktion og herunder industrien og fremstillingserhvervet er et centralt erhverv i Norden. Erhvervet har på tværs af de nordiske lande haft en relativ høj produktivitetsvækst i forhold til resten af landenes økonomier. Samtidigt står erhvervet for en stor andel af de respektive lands samlede eksport. ${ }^{1}$

Det nordiske fremstillingserhverv har gennemlevet relativt store ændringer i de seneste to årtier. Beskæftigelsen inden for erhvervet har generelt været faldende, og der har været en tendens til stigende efterspørgsel efter mere kvalificeret arbejdskraft. Udviklingen skal blandt andet ses i sammenhæng med brugen af nye digitale produktionsteknogier og løbende automatisering af produktionen. Styring af produktionen gennem censordata og internet-of-things, robotteknologier og 3D-printere er eksempler på disse.

${ }^{1}$ Digitalisation and automation in the Nordic manufacturing sector - Status, potentials and barriers (Iris Group for Nordic Council of Ministers 2015). 


\section{Kreative erhverv og design}

Kreative erhverv og design dækker over en lang række forskellige erhverv inden for områderne arkitektur, design, mode, møbeldesign samt reklame. Erhvervet omfatter både produktions- og servicevirksomheder. Erhvervet har internationalt set været i betydelig vækst i det seneste årti, blandt andet som følge af øget global velstand og nye informations- og kommunikationsteknologier. Udviklingen forventes at fortsætte i de kommende år i takt med den voksende middelklasse i de nye vækstlande. ${ }^{2}$

Området overlapper til dels væksterhvervene IKT og Grøn teknologi. Udbredelse af smartphones og tablets kan således forstærke efterspørgslen efter digitale produkter (computerspil og applikationer) med kreativt indhold. Samtidig er der en sammenhæng til Grøn teknologi gennem øget fokus på, hvordan man fremmer grøn omstilling gennem $\mathrm{fx}$ miljøvenlig arkitektur og design af produkter og emballage.

\section{Grøn teknologi}

Dette erhverv dækker over brugen af forskellige miljøvidenskaber til at begrænse menneskenes indflydelse på miljø og ressourcer. Områder omfatter blandt andet vedvarende energi, genbrug og udvikling af energieffektive produkter og fx digitale redskaber til energibesparing og miljøforbedringer.

De nordiske lande har en række styrkepositioner inden for erhvervet, og det er et erhverv med stor politisk fokus, særligt inden for udvikling og produktion af vedvarende energi. ${ }^{3}$ De nordiske energivirksomheder har endvidere mange års tradition for at samarbejde og råder tilsammen over store mængder råstoffer af meget forskellig art.

\section{Life Science}

Dette erhverv omfatter de delvist overlappende arbejdsmarkeder inden for medico-, bioteknologi-, pharma- og fødevareområdet. Bioteknologi er arbejdet med at anvende biologiske systemer, levende organismer, eller afledninger deraf, til at skabe eller ændre produkter eller processer til brug i blandt andet fødevare- og medicinalindustrien.

${ }^{2}$ Danmark i arbejde - Vækstplan og strategier for kreative erhverv og design (Erhvervs og Vækstministeriet 2013).

3 The Nordic Region - Leading in Green Growth, status report for the Nordic Prime Ministers Summer Meeting 2015. 
Medico består blandt andet af virksomheder, der udvikler, producerer og sælger medicinsk udstyr.

Der er tale om et væksterhverv i Norden, som er stærkt vidensintensivt og i stærk global konkurrence. Hele Life Science-området er desuden kendetegnet ved store investeringer i forskning- og udvikling. Et højt forsknings- og uddannelsesniveau i kombination med et højt teknologisk niveau er derfor en forudsætning for erhvervets styrkepositionen og fremtidige vækstmuligheder.

\subsection{Metode og datagrundlag}

Undersøgelsens resultater baserer sig på en spørgeskemaundersøgelse blandt virksomheder inden for de fem væksterhverv i Sverige, Danmark og Norge. Spørgeskemaundersøgelsen blev gennemført elektronisk (via e-mail) i perioden fra uge 44 til uge 48 i 2016, og der blev udsendt spørgeskema til 5.850 virksomheder og indsamlet 1.723 svar. Svarprocenten er således på 29 \% Se Appendiks for en detaljeret opgørelse af svarprocenter.

I rapporten anvendes en statistisk analyse af online jobopslag, som et nyt redredskab til at analysere virksomheders arbejdskraftsefterspørgsel. På baggrund af jobopslagsanalysen gennemføres en målrettet spørgeskemaundersøgelse til virksomheder inden for de fem væksterhverv i Sverige, Danmark og Norge, som for nyligt har forsøgt at rekruttere arbejdskraft inden for de identificerede væksterhverv. Jobopslagsanalysen er baseret på HBS-Jobindex-databasen, som er nærmere beskrevet i boks 2 .

\section{Boks 2: HBS-Jobindex-databasen}

Højbjerre Braver Schultz har i samarbejde med Jobindex udviklet HBS-Jobindex-databasen, som indeholder jobopslag for Sverige, Danmark og Norge. Databasen dækker alle lande perioden 2011-2016 (til og med november) og omfatter Jobindex' egne jobopslag såvel som jobopslag fra andre jobportaler og virksomheders hjemmesider. Databasen dækker stort set alle offentligt tilgængelige jobopslag. I Danmark indeholder databasen fx mere end to mio. jobopslag, og den opdateres hver måned med i gennemsnit ca. 20.000 nye jobopslag.

Ved hjælp af tekstanalyse trækkes de væsentligste informationer ud af hvert jobopslag. Det drejer sig blandt andet om jobfunktion. Hvert jobopslag kategoriseres herefter efter ISCO (internationalt klassifikationssystem for stillingsbetegnelser). Ligeledes udtrækkes viden fra jobopslag omkring kontaktpersoner på virksomheden (mail og navn). Der sendes efterfølgende en e-mail til virksomheder, 
som har forsøgt at rekruttere de relevante medarbejdere. Mailen sendes direkte til den person i virksomheden, som er kontaktperson i de pågældende jobopslag. Den samme virksomhed kan indgå flere gange, hvis den har søgt efter flere medarbejdere i perioden. I disse tilfælde vil der oftest være kontaktet forskellige kontaktpersoner i virksomheden.

Den jobopslagsbaserede udvælgelse gør det muligt direkte at kontakte virksomheder (via de identificerede kontaktpersoner) i de tre lande, som har forsøgt at rekruttere arbejdskraft inden for de fem væksterhverv.

De udvalgte væksterhverv er kendetegnet ved, at de i en vis udstrækning går på tværs af en traditionel brancheinddeling (NACE). For eksempel findes IKT og de tilhørende jobfunktioner inden for en lang række forskellige brancher. Udover egentlige IKT-virksomheder fylder erhvervet meget inden for $\mathrm{fx}$ branchen Finansiering og forsikring. Afgrænsningen af arbejdsmarkederne skal således gå på tværs af de traditionelle brancher.

For hvert af de udvalgte væksterhverv er der defineret et tilknyttet arbejdsmarked. Konkret er disse defineret ud fra en række nøgle-jobfunktioner, som er særligt centrale for de enkelte erhverv. I praksis kan den samme jobfunktion indgå i flere væksterhverv, men for simpelhedens skyld er alle jobfunktioner udelukkende tilknyttet det væksterhverv, hvor de fylder mest.

Jobfunktionerne er baseret og udvalgt på baggrund af den internationale klassifikation af jobfunktioner (ISCO). Figuren nedenfor viser de fem udvalgte væksterhverv og eksempler på relaterede nøgle-jobfunktioner.

Væksterhvervet Grøn teknologi går på tværs af en række forskellige arbejdsfunktioner i de øvrige væksterhverv. Udvælgelsen af dette erhverv sker derfor på baggrund af virksomhedernes egen vurdering af, om der er tale om en jobfunktion, som vedrører grøn teknologi. I opgørelsen vil kategorien Grøn teknologi hermed indeholde respondenter, som også indgår i de andre væksterhverv. ${ }^{4}$

Jobfunktionerne er desuden afgrænset til job, som forudsætter viden på mellemniveau (ISCO 3 ) eller højeste niveau (ISCO 2 ) inden for pågældende område.

For erhvervet Digital og automatiseret produktion er der imidlertid medtaget nogle jobfunktioner på lavere kvalifikationsniveau (primært forskellige former for operatører

4 Omkring $1 / 3$ af respondenterne svarer, at de i høj grad eller nogen grad arbejder inden for området "Grøn teknologi" 
og produktionsmedarbejdere). Der er i analysen ikke medtaget ledere (ISCO 1), ligesom der ikke er medtaget støttefunktioner inden for $\mathrm{fx}_{\mathrm{x}}$ salg og markedsføring (ISCO 4 og 5 ).

Figur 1: Væksterhverv og eksempler på nøglejobfunktioner

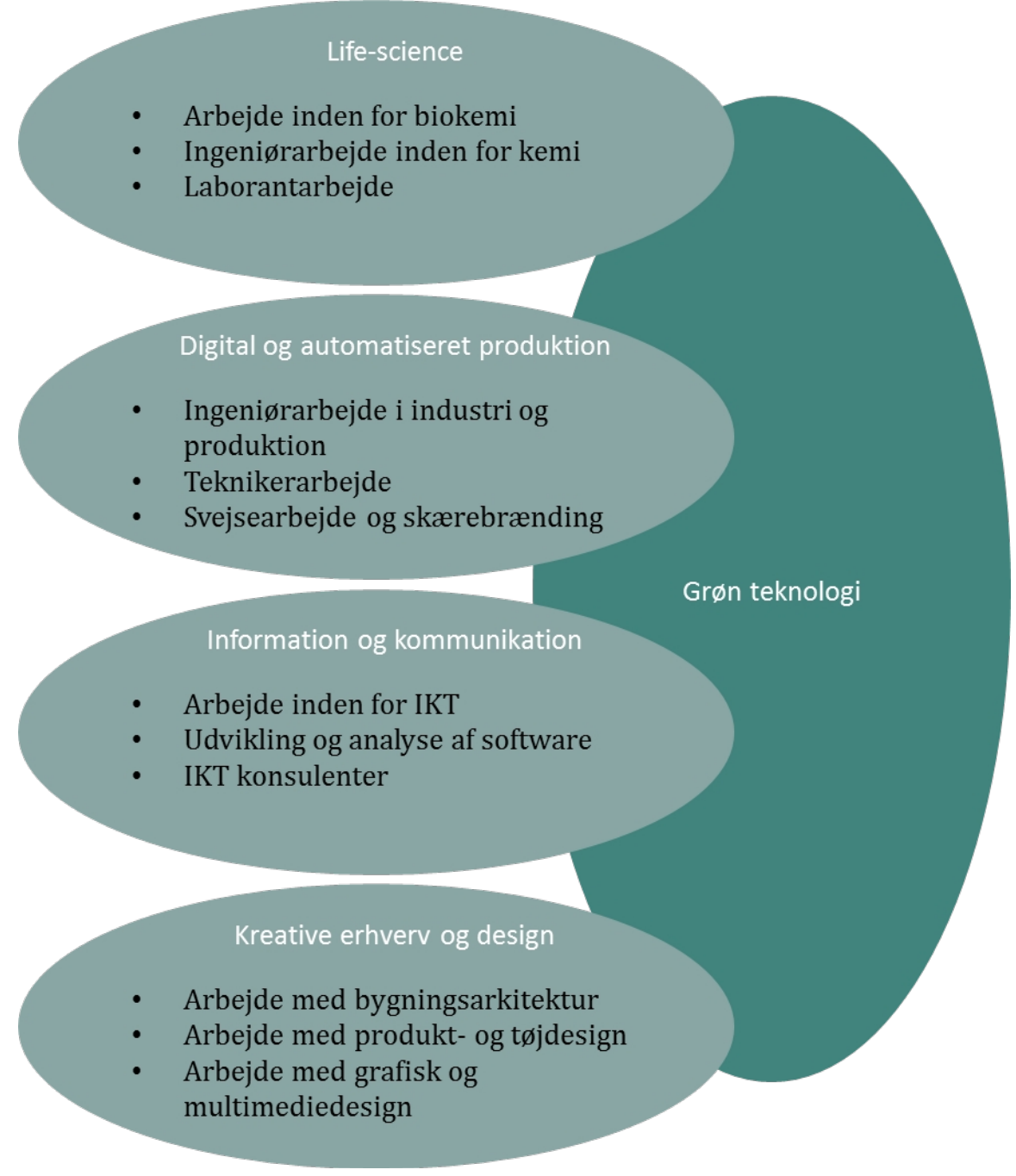

1.3 Undersøgelsens præmisser 
I forhold til fortolkning af undersøgelsens resultater er det vigtigt af være opmærksom på følgende usikkerhedselementer.

\subsubsection{Selvrapporterede svar}

Undersøgelsen tager udgangspunkt i virksomhedernes egen vurdering af situationen på arbejdsmarkedet. Centralt i undersøgelsen er fx virksomhedernes angivelse af, om det respektive rekrutteringsforsøg har været forgæves. Det vil sige, om de har opgivet at ansætte eller har måttet ansætte en medarbejder med en anden profil end den, de søgte efter. ${ }^{5}$ Dette indeholder en subjektiv vurdering fra kontaktpersonen på virksomheden, og det kan i sig selv betyde en forskel på vurderingen fra kontaktperson til kontaktperson, hvilket giver et element af usikkerhed i sammenligningen af resultaterne.

Kvaliteten i besvarelserne vurderes til gengæld til at være høj, da der er tale om en person, som har været direkte involveret i ansættelsen (nævnt som kontaktperson i jobopslaget). Dette giver i forhold til tidligere spørgeskemaundersøgelser, hvor virksomheder kontaktes gennem en central HR-funktion eller hovedmailadresse, en højere kvalitet i besvarelserne.

I undersøgelsen spørges også ind til kontaktpersonens generelle vurdering af en række forhold omkring rekrutteringssituationen. I forhold til de spørgsmål, som ikke kun vedrører den konkrete stilling nævnt i jobopslaget, vurderes kontaktpersonens svar også at være af relativ høj kvalitet. Det skyldes, at kontaktpersonen forventes at have mere indgående kendskab til erhvervets specialiserede arbejdsmarked end fx en generel HR-funktion.

\subsubsection{Bortfald og statistisk usikkerhed}

Der er tale om en spørgeskemaundersøgelse, og resultaterne er derfor omfattet af en statistisk usikkerhed, da der kun findes svar fra en stikprøve af den fulde population. For aggregerede tal er den maksimale usikkerhed med 2 procentpoint $(+/-)$, mens den maksimalt er 4 procentpoint for resultater opdelt på væksterhverv. I resultater, hvor væksterhvervene er landeopdelt kan usikkerheden være højere. I disse tilfælde er der

5 En tilsvarende definition bruges af Beskæftigelsesministeriet i Danmark i omfattende virksomhedssurvey som hvert halve år kortlægger manglen på arbejdskraft. 
gjort eksplicit opmærksomt på det i teksten, og der er ikke konkluderet på forskelle, som ikke er statistisk signifikante.

Udover den statistiske usikkerhed er der risiko for skævhed i resultaterne som følge af systematisk frafald i besvarelserne, da den samlede svarprocent er på ca. $30 \%$, hvilket dog er sammenligneligt med andre spørgeskemaundersøgelser til virksomheder. Der er ikke observeret større systematiske tendenser i frafaldet landene imellem, og frafaldet har således primært betydning for niveauet i de angivne andele, og i mindre grad for de relative sammenligninger på tværs af lande og væksterhverv. Risikoen for underliggende systematiske forskelle i frafaldet kan imidlertid ikke udelukkes, men vurderes ikke at være højere end $i$ andre spørgeskemaundersøgelser. Usikkerheden og frafaldet er nærmere beskrevet i Appendiks.

\subsubsection{Repræsentativitet}

En central analytiske enhed i spørgeskemaundersøgelsen er virksomhedernes rekrutteringsforsøg via jobopslag. Resultaterne vurderes at være repræsentative for virksomheder, der benytter jobopslag inden for det enkelte væksterhverv. Da der er tale om en undersøgelse, som primært fokuserer på kvalificeret arbejdskraft, hvor en relativ stor andel virksomheder bruger jobopslag, vurderes resultaterne også at være repræsentative for rekrutteringsforsøg blandt virksomheder, som ikke bruger jobopslag. Systematiske forskelle i brugen af jobopslag mellem lande udgør imidlertid et usikkerhedselement. Det kan fx være forskel på hvilke type stillinger inden for et væksterhverv, som virksomhederne slår op.

Som følge af den jobopslagsbaserede målretning mod rekrutteringsforsøg for virksomheder i de enkelte væksterhverv er resultaterne ikke repræsentative for væksterhvervene samlet set. For eksempel vil de samlede rekrutteringsudfordringer $\mathrm{i}$ et land afhænge af, hvor stor en andel de enkelte væksterhverv udgør af den samlede jobomsætning i landet. Når der i undersøgelsen sker sammenligninger på tværs af lande, vil det ske inden for de enkelte væksterhverv eller som et simpelt gennemsnit på tværs af væksterhvervene (for at sikre en sammenlignelig fordeling mellem lande). 


\section{Omfang og konsekvens af rekrut- teringsudfordringer}

\subsection{Omfanget af rekrutteringsudfordringer i nordiske væksterhverv}

Knap hver fjerde af de virksomheder inden for de udvalgte væksterhverv, som har forsøgt at rekruttere arbejdskraft, har haft rekrutteringsudfordringer. Det dækker over en række forskelle på tværs af lande såvel som mellem de udvalgte væksterhverv.

På tværs af de tre lande er rekrutteringsudfordringerne størst inden for IKT. Her er mere end 3 ud af 10 rekrutteringsforsøg forgæves, jf. figur 2 . Rekrutteringsudfordringerne er mindst inden for Life Science, hvor ca. $13 \%$ af rekrutteringsforsøgene er forgæves.

Figur 2: Forgæves rekrutteringsforsøg i nordiske væksterhverv

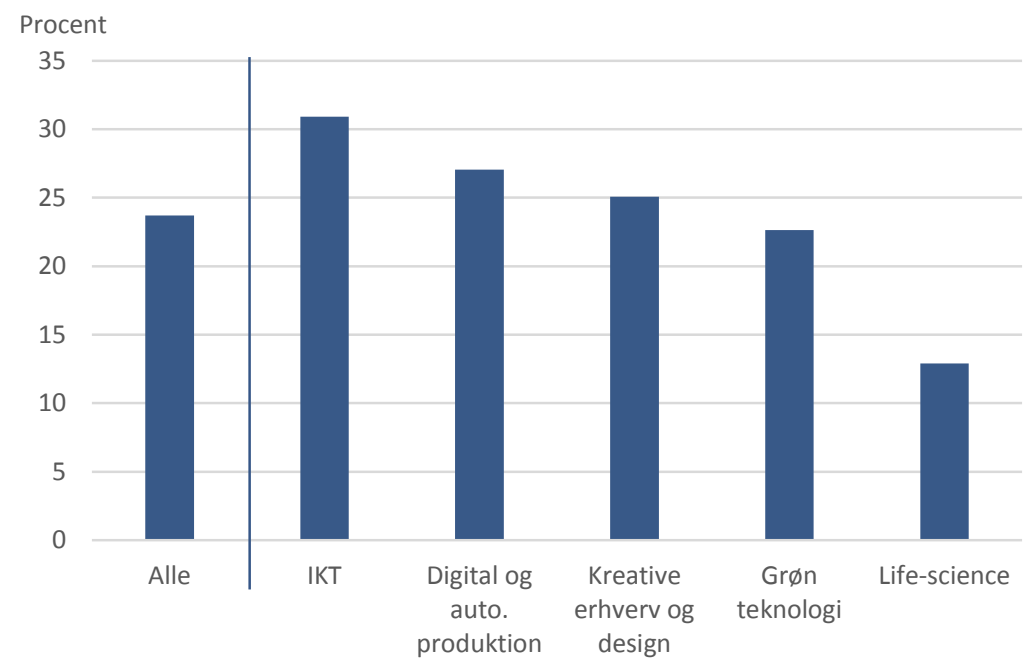

Note: Søjlen Alle dækker over et gennemsnit af de fem væksterhverv. Spørgsmål: Var rekrutteringsforsøget via stillingsopslaget succesfuldt? $\mathrm{N}=1709$ (IKT=427, $\mathrm{DP}=326, \mathrm{KD}=407, \mathrm{GT}=609, \mathrm{LS}=521)$.

Kilde: Spørgeskemaundersøgelse på baggrund af HBS-Jobindex. 
På tværs af væksterhvervene er mere end 4 ud af 10 virksomheder helt enig eller meget enig $i$, at det er en udfordring af rekruttere den rette arbejdskraft, jf. figur 3 .

Virksomhedernes generelle syn på rekrutteringssituationen bekræfter også billedet af, at rekrutteringsudfordringerne er størst inden for IKT og Digital og automatiseret produktion, mens den er mindre inden for Life Science.

Figur 3: Er virksomheden enig l, at det er svært at rekruttere det rette arbejdskraft?

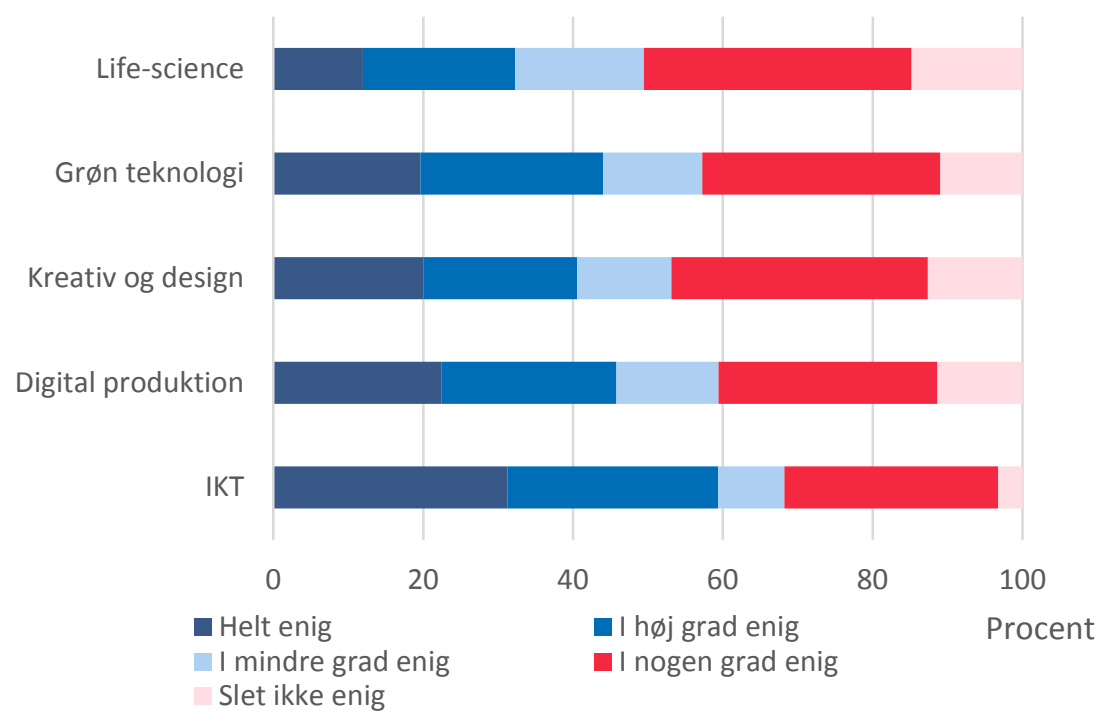

Note: Spørgsmål: I hvor høj grad er du enig i følgende udsagn: Det er svært at rekruttere medarbejdere med de rette kompetencer til stillingens arbejdsområde? $N=1663$ (LS=493, GT=566, KD=365, $\mathrm{DP}=308, \mathrm{IKT}=406$ ).

Kilde: Spørgeskemaundersøgelse på baggrund af HBS-Jobindex.

Rekrutteringsudfordringerne i de nordiske væksterhverv går på tværs af uddannelsesbaggrund. Således er der i de enkelte væksterhverv relativt mange forgæves rekrutteringer blandt rekrutteringsforsøg, som vedrører både lange og kortere uddannelser. 
Eksempelvis er det inden for IKT næsten hver tredje rekrutteringsforsøg som er forgæves for både lange, mellemlange og korte videregående uddannelser.

\subsection{Omfanget af rekrutteringsudfordringer i de enkelte lande}

På tværs af væksterhvervene er rekrutteringsudfordringerne overordnet set størst i Sverige. I Sverige er det således i gennemsnit $29 \%$ af rekrutteringsforsøgene, som er forgæves på tværs af de fem væksterhverv. Til sammenligning er tallet 25 \% i Danmark og $19 \%$ i Norge. $^{6}$

I figuren nedenfor er vist andelen af rekrutteringsforsøg, som er forgæves. Med undtagelse af Kreative erhverv og design har Sverige den højeste andel af forgæves rekrutteringer. Med undtagelse af IKT har Norge den laveste andel af forgæves rekrutteringer inden for alle væksterhverv.

På tværs af lande findes den højeste andel af forgæves rekrutteringer inden for IKT, hvor 3 ud af 10 rekrutteringsforsøg er forgæves. Desuden viser figuren, at der er relativt store rekrutteringsudfordringer inden for Kreative erhverv og design i Danmark, som ikke kan genfindes i Sverige og Norge. På tværs af de tre lande ligger rekrutteringsudfordringerne lavest inden for Life Science.

${ }^{6}$ Simpelt gennemsnit af rekrutteringsudfordringerne i de fem væksterhverv. 
Figur 4: Andel forgæves rekrutteringer af samtlige rekrutteringsforsøg

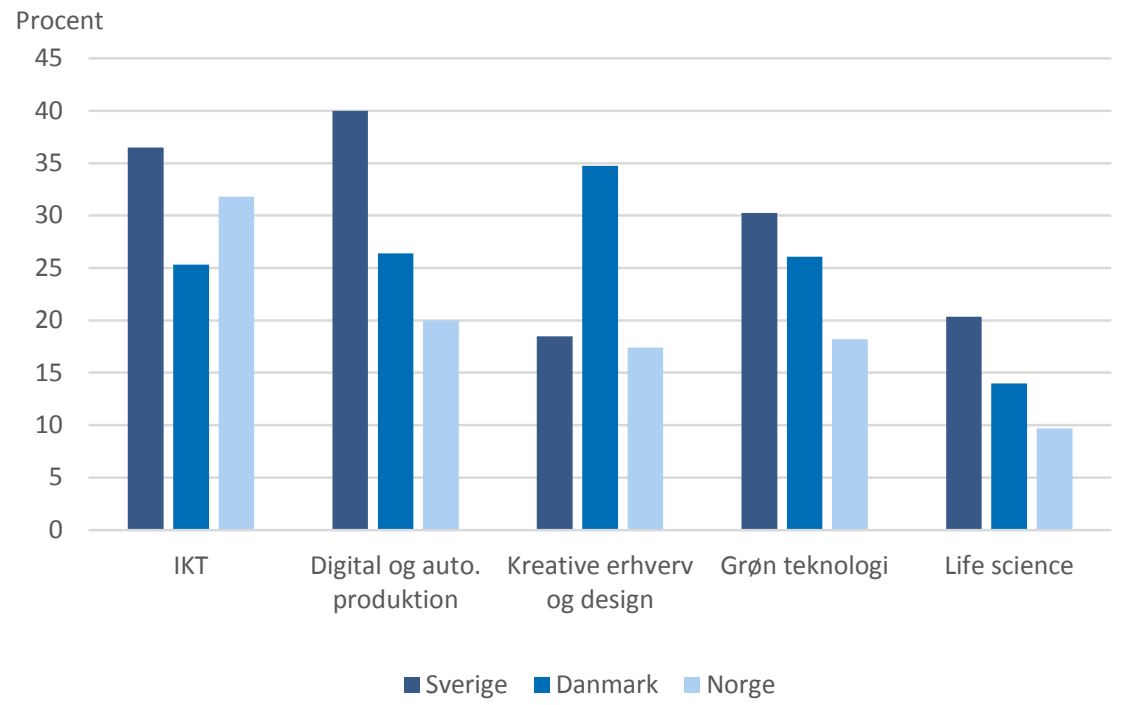

Note: Spørgsmål: Var rekrutteringsforsøget via stillingsopslaget succesfuldt? Med et succesfuldt rekrutteringsforsøg menes, at virksomheden afsluttede den pågældende rekruttering med at ansætte en medarbejder med de ønskede kvalifikationer. $\mathrm{N}=1709$ ( $\mathrm{SV}=409, \mathrm{DK}=724, \mathrm{NO}=576)$.

Kilde: Spørgeskemaundersøgelse på baggrund af HBS-Jobindex.

\subsection{De seneste tre års udvikling i rekrutteringsudfordringer}

På tværs af lande og væksterhverv er det ca. en tredjedel af virksomhederne, som vurderer, at rekrutteringsudfordringerne er blevet forværret de seneste tre år.

Der er betydelige variation mellem de tre lande. Således er der $52 \%$ af virksomhederne i Sverige, som vurderer, at rekrutteringsudfordringerne er blevet forværret de seneste tre år. I Danmark er tallet $42 \%$, mens det kun er $15 \%$ af virksomhederne i Norge, som vurderer, at rekrutteringsudfordringerne er blevet værre de seneste år. Rekrutteringsudfordringerne vil afhænge af udviklingen i den generelle konjunktursituation i landende, hvor en faldende ledighed og øget økonomisk aktivitet alt andet lige vil trække i retning af større rekrutteringsudfordringer. 
Figur 5 viser sammenhængen mellem den nuværende rekrutteringssituation og udviklingen heri de seneste tre år på tværs af lande og væksterhverv. Særligt væksterhvervene Digital og automatiseret produktion og IKT i Sverige og Danmark er kendetegnet ved en høj andel af forgæves rekrutteringer. Det ses også, at situationen er forværret de seneste tre år.

Figur 5: Sammenhæng mellem vurdering af de nuværende situation og udviklingen de seneste tre år

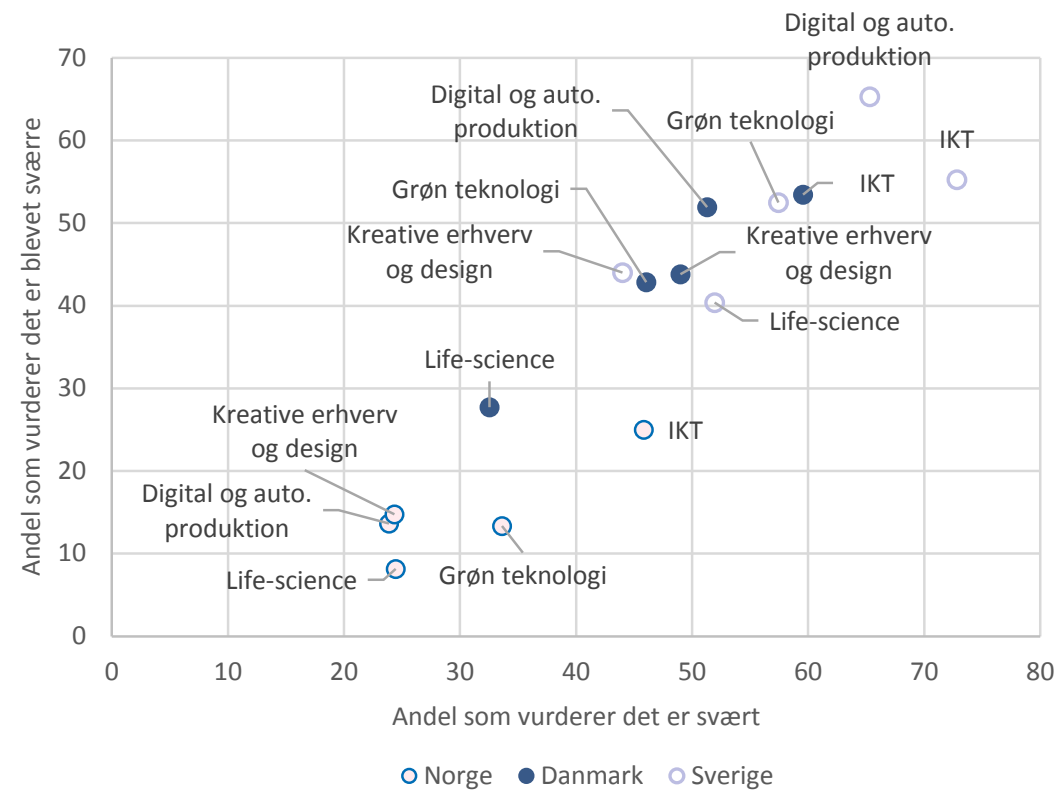

Note: Spørgsmål: I hvor høj grad er du enig i følgende udsagn: Det er svært at rekruttere medarbejdere med de rette kompetencer til stillingens arbejdsområde? Og I hvor høj grad er du enig i følgende udsagn: Det er de seneste tre år blevet sværere at rekruttere de rette kompetencer inden for stillingens arbejdsområde? $\mathrm{N}=1498(\mathrm{NO}=507, \mathrm{SV}=343, \mathrm{DK}=648)$.

Kilde: Spørgeskemaundersøgelse på baggrund af HBS-Jobindex. 


\subsection{Konsekvenser af rekrutteringsudfordringer}

Rekrutteringsudfordringerne kan have en række økonomiske konsekvenser for virksomheder. I gennemsnit svarer $36 \%$ af virksomhederne, at rekrutteringsudfordringen har medført, at de har måtte udskyde eller aflyse nogle af virksomhedens aktiviteter.

I figur 6 er andelen, som har svaret, at de har måtte udskyde eller droppe aktiviteter på grund af forgæves rekrutteringer, holdt op imod andelen af forgæves rekrutteringer.

De væksterhverv, der ligger i øverste højre hjørne, har relativt store rekrutteringsudfordringer, samtidigt med at rekrutteringsudfordringerne har relativt store konsekvenser for deres forretning. Det drejer sig om IKT og Digital og automatiseret produktion i Sverige og Kreative erhverv og design i Danmark.

Der er ikke nogen stærk positiv sammenhæng mellem de to størrelser. Det skal bemærkes, at spørgsmålet omkring produktionsbegrænsningerne vedrører her-og-nukonsekvensen af rekrutteringsudfordringen. Det kan forventes, at rekrutterings-udfordringerne dertil kan få økonomiske konsekvenser på længere sigt, fx lavere fremtidig vækstmuligheder. 
Figur 6: Sammenhæng mellem andel forgæves rekrutteringer og andel med produktionsbegrænsning

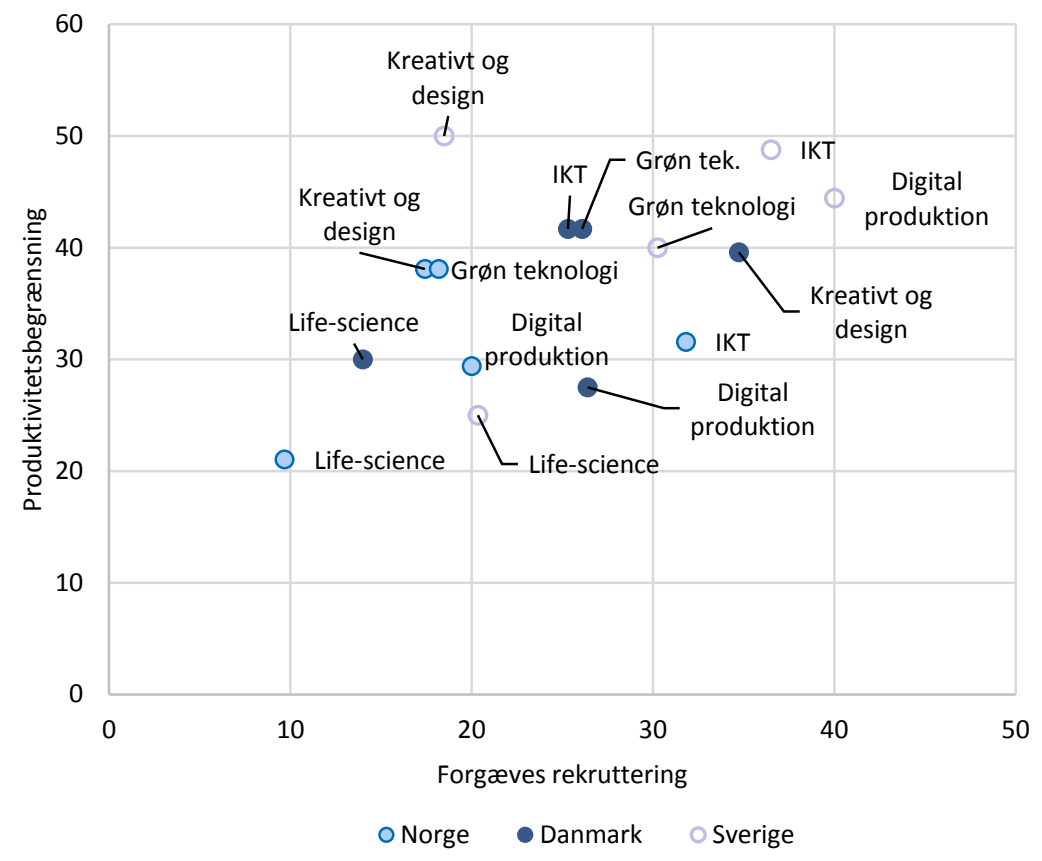

Note: Spørgsmål: 1.aksen: Har problemer i forbindelse med rekrutteringen betydet, at virksomheden har opgivet eller udskudt ordrer eller andre aktiviteter? 2.aksen: Var rekrutteringsforsøget via stillingsopslaget succesfuldt? $\mathrm{N}=1709$ (IKT=455, DP=326, KD=407, GT=609, LS=521).

Kilde: Spørgeskemaundersøgelse på baggrund af HBS-Jobindex.

Endvidere har rekrutteringsudfordringer medført, at omkring en tredjedel af virksomhederne enten har opgivet af rekruttere eller måtte ansætte en medarbejder med en anden kompetenceprofil en tiltænkt. 
Figur 7: Er stillingen blevet besat siden rekrutteringsforsøget?

Ja, stillingen er besat

Ja, stillingen er besat, men med en anden faglig profil end vi oprindeligt havde forestillet os

Nej, vi søger stadig

Nej, vi har opgivet at rekruttere

Nej, stillingen er nedlagt

Nej, anden årsag
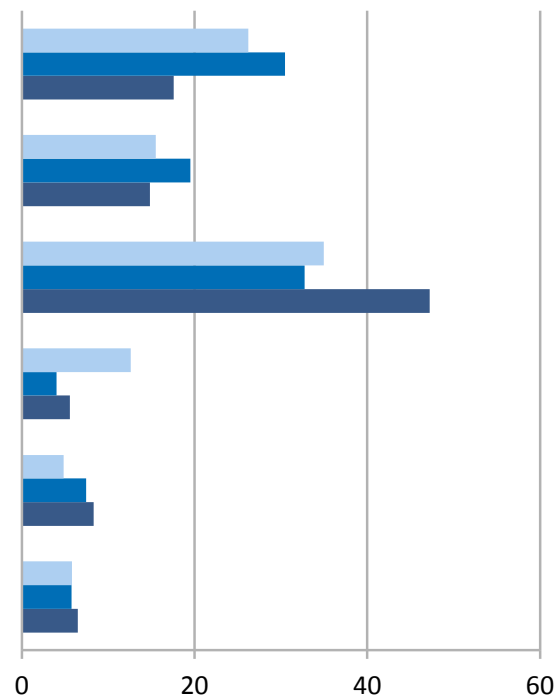

Procent

Sverige $\quad$ Danmark Norge

Note: Spørgsmål: Er stillingen besat i dag? $\mathrm{N}=385(\mathrm{SV}=122, \mathrm{DK}=174, \mathrm{NO}=104)$.

Kilde: Spørgeskemaundersøgelse på baggrund af HBS-Jobindex.

Den forgæves rekruttering udgør relativt ofte en produktionsbegrænsning, hvis stillingen slet ikke kan besættes. I dette tilfælde svarer $39 \%$, at det medfører produktionsbegrænsninger, jf. figur 8.

Undersøgelsen viser derudover, at selvom stillingen i sidste ende ender med at blive besat, $\mathrm{fx}$ med en anden profil end tiltænkt, kan det relativt ofte også medføre produktionsbegrænsninger. Således svarer $33 \%$ af de virksomheder, der har haft en forgæves rekruttering, men alligevel ansat, at det har betydet en produktionsbegrænsning. Dette peger på, at rekrutteringsudfordringer relativt ofte kan have økonomiske konsekvenser for virksomheder, hvis de får besat stillingen med en anden profil end tiltænkt. 
Figur 8: Andel med produktionsbegrænsninger blandt virksomheder med rekrutteringsudfordringer fordelt efter, om stillingen er blevet besat

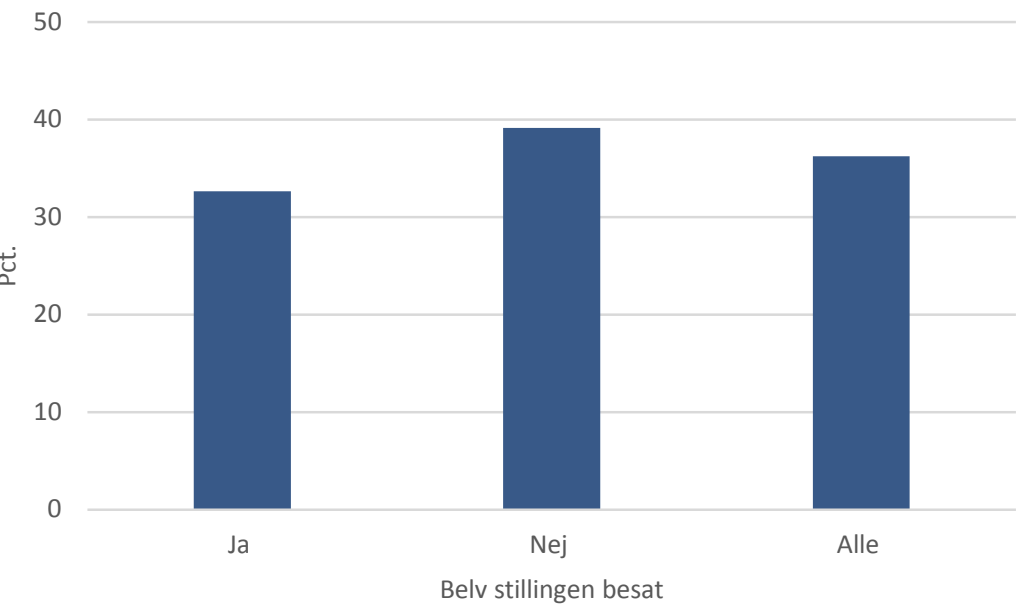

Note: Omfatter kun respondenter, som har svaret, at rekrutteringsforsøget ikke var succesfuldt. Andel med produktionsbegrænsninger er udregnet som den andel, der har svaret ja til spørgsmålet: Har problemer i forbindelse med rekrutteringen betydet, at virksomheden har opgivet eller udskudt ordrer eller andre aktiviteter?

Kilde: Spørgeskemaundersøgelse på baggrund af HBS-Jobindex. 



\section{3. Årsager til rekrutteringsudfordrin- ger og vurdering af uddannelser}

\section{1 Årsager til den forgæves rekruttering}

Halvdelen af de virksomheder, som har haft en forgæves rekruttering, peger på manglende tekniske kompetencer hos ansøgerne som en årsag til rekrutteringsudfordringen, jf. figur 9 . 4 Ud af 10 virksomheder peger desuden på ansøgernes manglende erfaring som en årsag.

Omkring 14 \% peger på manglende ansøgere, som en årsag til rekrutterings-udfordringerne, mens $16 \%$ svarer, at mangel på formel uddannelse er en årsag. Virksomheder peger ligeledes på, at mindre end $5 \%$ af de forgæves rekrutteringsforsøg skyldes venigheder om ansættelsesvilkår.

Undersøgelsen peger således på, at rekrutteringsudfordringerne både skyldes et indholdsmæssigt mismatch mellem virksomheders efterspørgsel og udbuddet af kompetencer (kompetencer og erfaring) og et volumenmæssigt mismatch i udbud og efterspørgsel af arbejdskraft (manglende ansøgere og mangel på ansøger med formelle uddannelser). 
Figur 9: Hvad var årsagerne til den forgæves rekruttering

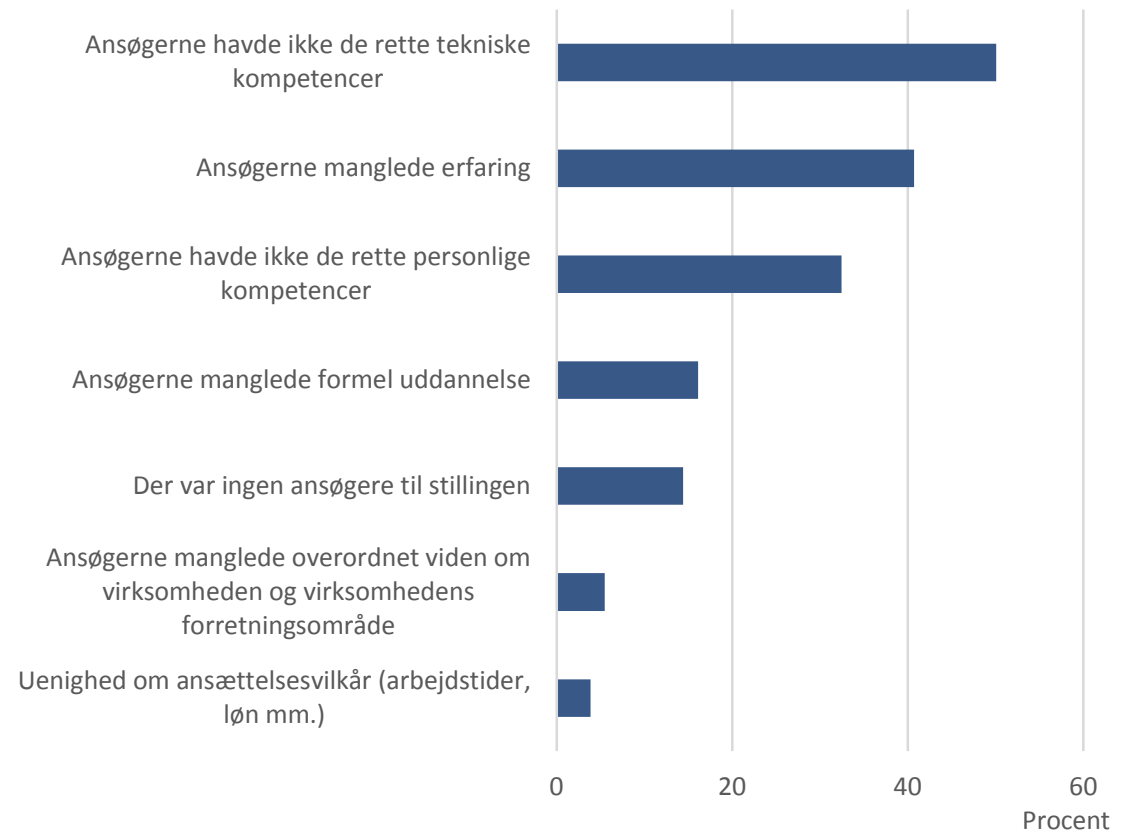

Note: Spørgsmål: Hvad var årsagerne til den forgæves rekruttering?

Virksomheder, som har haft en forgæves rekruttering, er spurgt. Det er muligt at vælge flere årsager. $\mathrm{N}=368$.

Kilde: Spørgeskemaundersøgelse på baggrund af HBS-Jobindex.

\subsection{Vurdering af uddannelserne}

I spørgeskemaundersøgelsen bliver virksomhederne bedt om at vurdere, i hvor høj grad de respektive uddannelser inden for erhvervet dækker virksomhedens kompetencebehov. På tværs af lande og væksterhverv svarer mere end 6o \% af virksomhederne, at uddannelserne dækker deres respektive kompetencebehov i meget høj eller høj grad.

Uddannelser inden for Digital og automatiseret produktion dækker i mindre grad virksomhedernes behov, mens uddannelser inden for Life Science dækker virksomhedernes behov i større grad, jf. figur 10 . 
På tværs af de fem væksterhverv er andelen af virksomheder, som vurderer, at deres kompetencebehov dækkes, generelt lidt lavere i Sverige end i Danmark og Norge.

Figur 10: Andel, som er helt eller meget enig i, at uddannelserne dækker virksomhedens behov

\section{Procent}

100

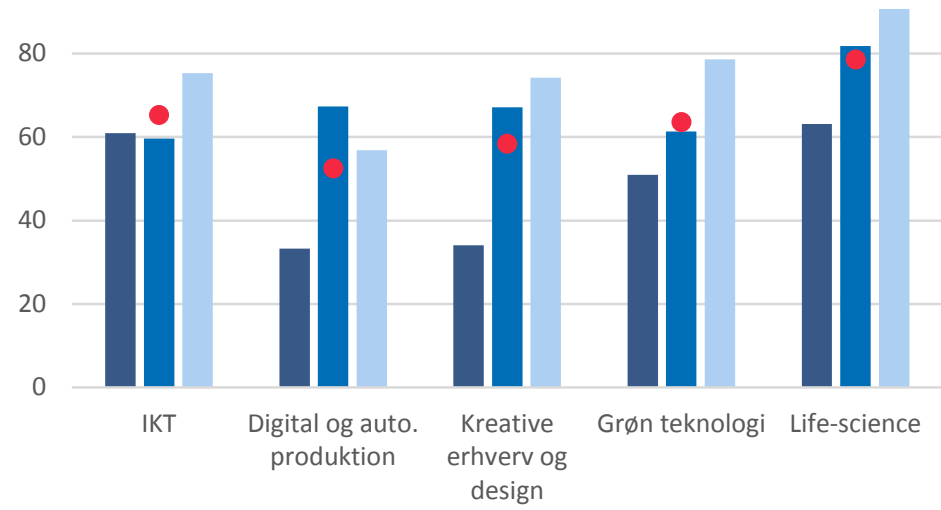

- Sverige @ Danmark $\square$ Norge $\bullet$ Gennemsnit

Note: Spørgsmål: I hvor høj grad giver de uddannelser, der er relevante for stillingen, kvalifikationer, som dækker virksomhedens behov? $\mathrm{N}=1599$ ( $\mathrm{SV}=355, \mathrm{DK}=696, \mathrm{NO}=548$ ).

Kilde: Spørgeskemaundersøgelse på baggrund af HBS-Jobindex.

Der ses forskel i tilfredshed med uddannelserne landende imellem. I Sverige er det ca. halvdelen af virksomhederne, som svarer, at de relevante uddannelser, dækker virksomhedens behov i høj eller meget høj grad. 7 I Norge er tallet 8 ud af 10, mens 7 ud af 10 virksomheder i Danmark svarer, at de relevante uddannelser dækker deres behov $\mathrm{i}$ høj eller meget høj grad.

Figur 11 viser, hvor stor en andel af virksomheder, som mener, at deres kompetencebehov dækkes af uddannelserne, opdelt efter om virksomhederne har oplevet en forgæves rekruttering eller ej.

7 Udregnet som et simpelt gennemsnit af andelene i enkelte væksterhverv i hvert land. Hermed renses for eventuelle forskelle i svarprocenter mellem lande og væksterhverv. 
Virksomheder, som har oplevet en forgæves rekruttering, vurderer, at uddannelserne i mindre grad dækker deres kompetencebehov. Det indikerer, at virksomhedernes rekrutteringsudfordringer kan skyldes, at de kompetencer, man opnår på uddannelserne, ikke har et højt nok niveau, og/eller at uddannelserne ikke giver de studerende de kompetencer, som virksomhederne efterspørger.

Figur 11: Dækker de relevante uddannelser virksomhedernes behov

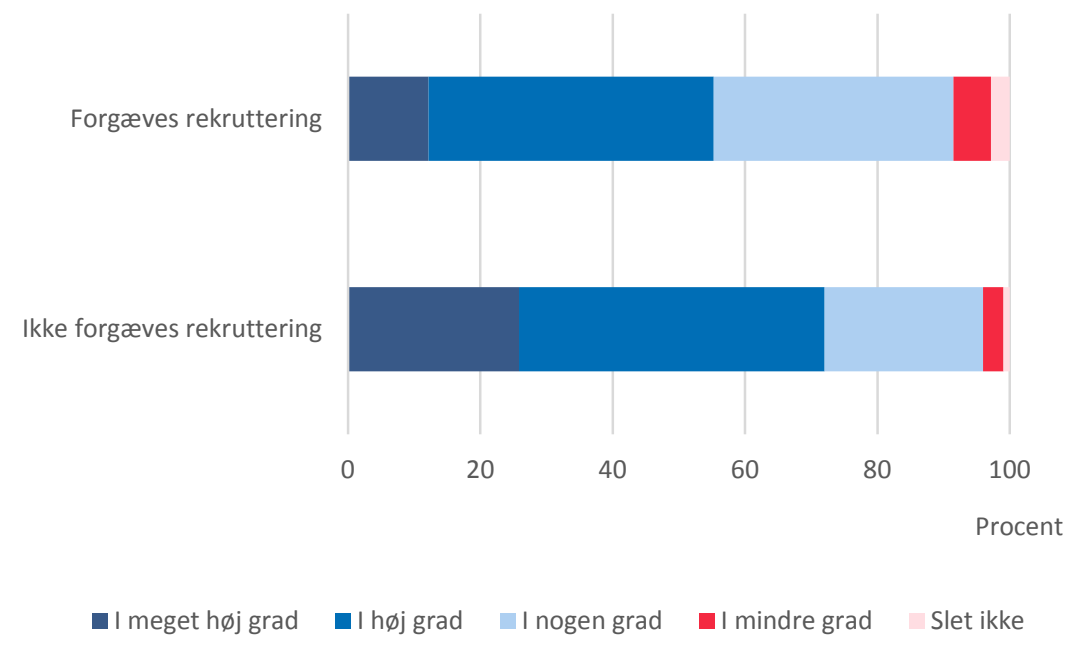

Note: Spørgsmål: I hvor høj grad giver de uddannelser, der er relevante for stillingen, kvalifikationer, som dækker virksomhedens behov? $\mathrm{N}=1579$ (Forgæves=382, Ikke forgæves=1197)

Kilde: Spørgeskemaundersøgelse på baggrund af HBS-Jobindex 


\section{Rekrutteringskanaler og virksom- hedernes løsningstiltag}

\subsection{Virksomhedernes brug af rekrutteringskanaler}

De mest udbredte rekrutteringskanaler er online jobopslag, som bruges af 7 ud af 10 virksomheder, jf. figur 12. Annoncering på egen hjemmeside bruges af 6 ud af 10 virksomheder, mens annoncering via de sociale medier anvendes af $5 \mathrm{ud}$ af 10 virksomheder. Der er kun 1 ud af 10 virksomheder, som anvender arbejdsløshedskasser, offentlige jobformidlinger eller lignende.

Figur 12: Hvordan søgte virksomheden efter ansøgere/kandidater til stillingen?

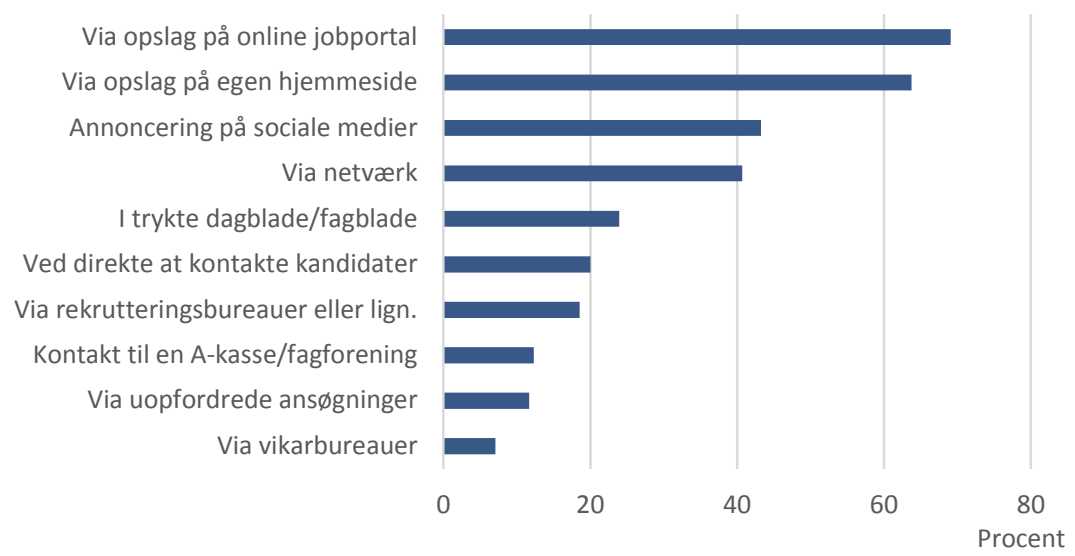

Note: Spørgsmål: Hvordan søgte virksomheden efter ansøgere/kandidater til stillingen? N=1696.

Kilde: Spørgeskemaundersøgelse på baggrund af HBS-Jobindex. 


\subsection{Rekruttering på tværs af de nordiske lande}

Omkring hver fjerde virksomhed forsøger i hovedreglen eller nogle gange at rekruttere fra de andre nordiske lande.

Virksomheder i Norge forsøger oftere at rekruttere fra andre nordiske lande end virksomheder i Sverige og Danmark, jf. figur 13 . I Norge er det mere end $40 \%$ af virksomhederne, som i hovedregelen eller nogle gange forsøger at rekruttere i andre nordiske lande. Denne andel er omkring dobbelt så høj som i Sverige og Danmark, hvor omkring $20 \%$ orienterer sig mod det nordiske arbejdsmarked.

Figur 13: Forsøger virksomheden at rekruttere $\mathrm{i}$ andre nordiske lande

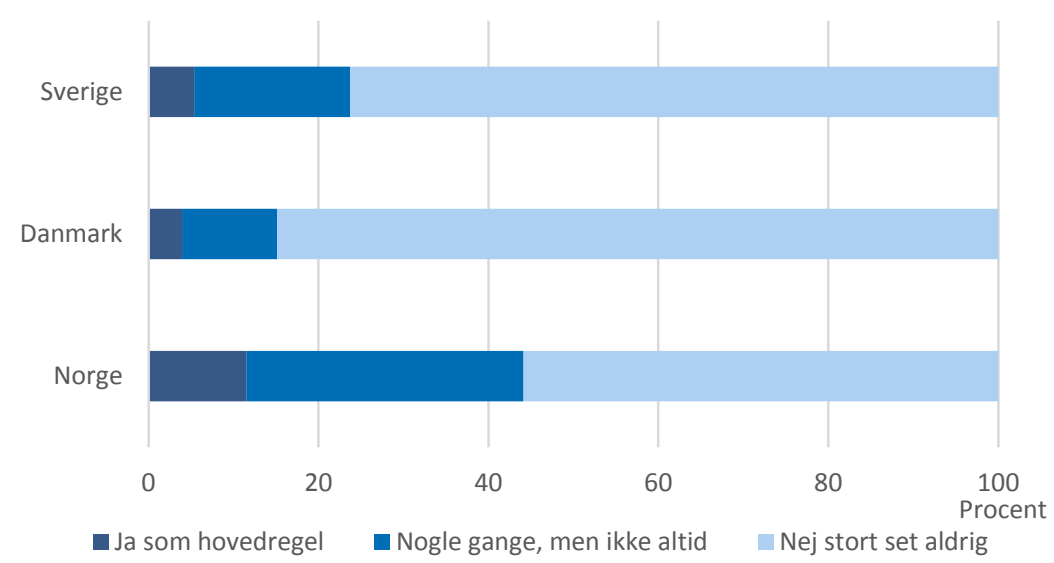

Note: Spørgsmål: Forsøger virksomheden systematisk at rekruttere arbejdskraft fra andre nordiske lande, $\mathrm{fx}$ gennem at slå stillinger elektronisk op i andre nordiske lande? $\mathrm{N}=1499(\mathrm{SV}=337, \mathrm{DK}=662, \mathrm{NO}=500)$.

Kilde: Spørgeskemaundersøgelse på baggrund af HBS-Jobindex.

I undersøgelsen er virksomhederne blevet bedt om at angive, hvilke barrierer der ses $\mathrm{i}$ forhold til at rekruttere i andre nordiske lande. Den barriere, som oftest nævnes, er familiemæssige hensyn. Omkring 4 ud af 10 virksomheder ser dette som en udfordring i forhold til at kunne rekruttere nordisk, jf. figur 14.

Sprog er også en barriere, som nævnes ofte. Hver fjerde virksomhed peger således på manglende sproglige kompetencer som en udfordring. Blot 1 ud af 10 virksomheder peger på løn og ansættelsesvilkår som en udfordring. 
Figur 14: Hvilke barrierer ser virksomheden i forhold til at rekruttere i andre nordiske lande?

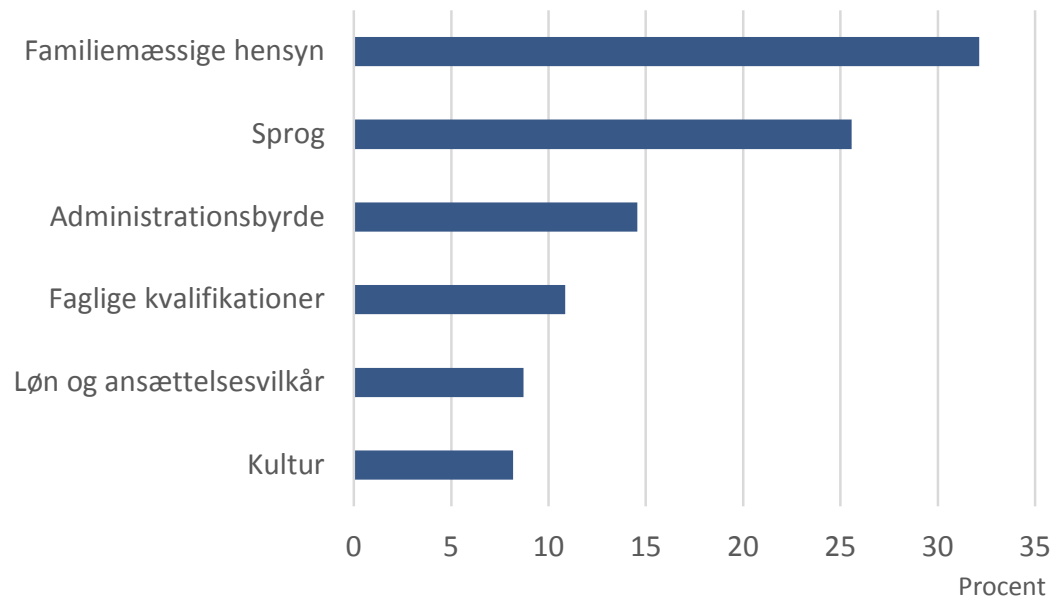

Note: Spørgsmål: I hvor høj grad vurderer l, at nedenstående er barrierer for at rekruttere arbejdskraft fra andre nordiske lande? $\mathrm{N}=1604$.

Kilde: Spørgeskemaundersøgelse på baggrund af HBS-Jobindex.

\subsection{Virksomhedernes løsningstiltag}

Virksomhederne bliver i undersøgelsen bedt om at angive, hvordan de forsøger at løse eventuelle rekrutteringsudfordringer.

Det mest brugte løsningstiltag er at søge ad flere omgange eller at søge via alternative søgekanaler. Omkring 1 ud af 4 virksomheder genopslår det samme opslag for at løse rekrutteringsudfordringer. Det andet mest brugte løsningstiltag er at benytte et bredere udsnit af rekrutteringskanaler ( $f x$ rekrutteringsfirmaer $m . v$.). Det tredje mest brugte løsningstiltag er at opkvalificere nuværende medarbejdere med efter- eller videreuddannelse.

Omkring 1 ud af 10 virksomheder vælger at søge efter kandidater blandt de nordiske lande for at modvirke rekrutteringsudfordringer. Få virksomheder har det som en løsningsstrategi at gøre forholdene mere lukrative for en potentiel ansøger ( $f x$ højere lønninger). 
Figur 15: Løsningstiltag i forhold til at modvirke rekrutteringsudfordringer

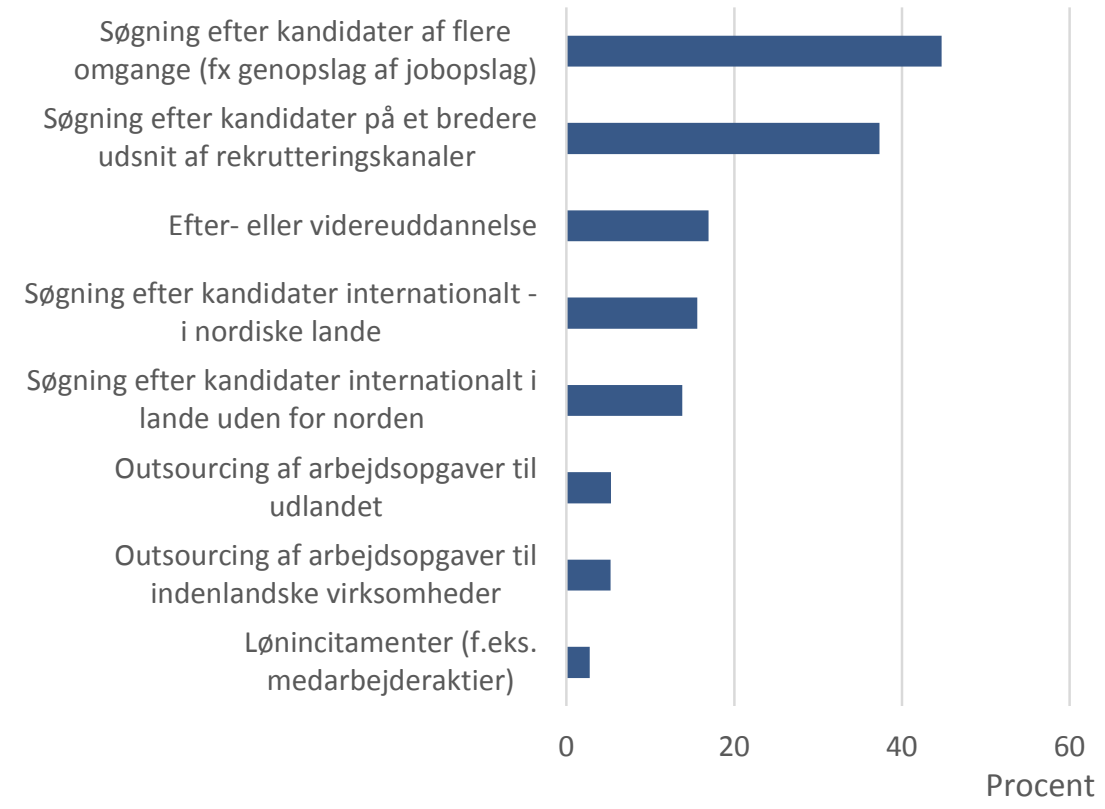

Note: Andel, som har angivet løsningstiltaget (kan summe til mere end $100 \%$ på grund af muligheden for at angive flere svar. Norden forstås som (Danmark, Norge, Sverige, Finland og Island). $\mathrm{N}=1335$.

Kilde: Spørgeskemaundersøgelse på baggrund af HBS-Jobindex.

Der er mindre forskelle på, hvordan virksomhederne i de enkelte væksterhverv forsøger at løse deres rekrutteringsudfordringer.

Der er således en tendens til, at virksomheder inden for Life Science og Kreative erhverv og design oftere end andre virksomheder forsøger at rekruttere internationalt, når de har rekrutteringsudfordringer, jf. figur 16 . Virksomheder inden for IKT gør lidt oftere brug af bredere rekrutteringskanaler ( $\mathrm{f} x$ brug af rekrutteringsfirmaer) end virksomheder inden for de andre væksterhverv, mens virksomheder inden for Digital og automatiseret produktion i højere grad benytter intern opkvalificering (efteruddannelse). 
Figur 16: Løsningstiltag i forhold til at modvirke rekrutteringsudfordringer

Søgning efter kandidater af flere omgange (fx genopslag af jobopslag)

Søgning efter kandidater på et bredere udsnit af rekrutteringskanaler

Efter- eller videreuddannelse

Søgning efter kandidater internationalt - i nordiske lande

Søgning efter kandidater internationalt

? i lande uden for norden

Outsourcing af arbejdsopgaver til udlandet

Outsourcing af arbejdsopgaver til indenlandske virksomheder

Lønincitamenter (f.eks. medarbejderaktier)

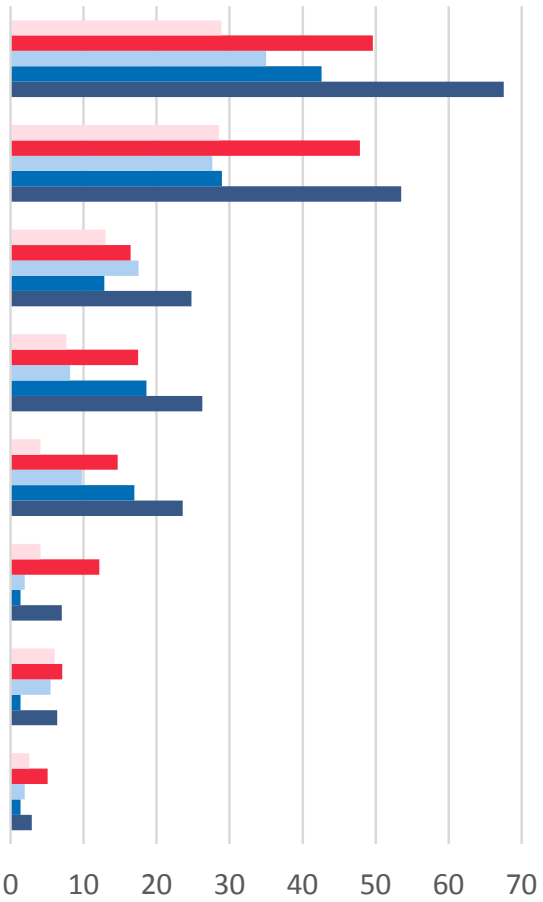

\footnotetext{
Kreativ og design
}

- Life-science

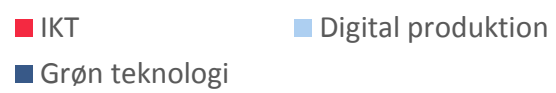

Procent

Note: Udvalgte løsningstiltag. Andel, som har angivet løsningstiltaget (kan summe til mere end $100 \%$ på grund af muligheden for at angive flere svar). $\mathrm{N}=1335$ ( $\mathrm{IKT}=395, \mathrm{DP}=257, \mathrm{KD}=315, \mathrm{GT}=484, \mathrm{LS}=366$ ).

Kilde: Spørgeskemaundersøgelse på baggrund af HBS-Jobindex.

Et muligt løsningstiltag på rekrutteringsudfordringer er at outsource opgaver. På tværs af væksterhvervene er det under $5 \%$ af virksomheder som angiver, at de benytter outsourcing til at løse rekrutteringsudfordringer. 
Brugen af outsourcing som løsningstiltag er forskellig på tværs af væksterhvervene. Virksomheder inden for IKT og Grøn teknologi har relativ høj tendens til at outsource, hvorimod virksomheder inden for Life Science relativt sjældent outsourcer opgaver som følge af rekrutteringsudfordringer.

Der er generelt forskel på, i hvor høj grad rekrutteringsudfordringer fører til øget brug af international rekruttering i virksomhederne i de enkelte væksterhverv.

Andelen af virksomheder, der forsøger at rekruttere nordiske kandidater som følge af rekrutteringsudfordringer, er højest inden for IKT, Grøn teknologi og Life Science. Indenfor Digital og automatiseret produktion og Kreative erhverv og design er andelen, som orienterer sig internationalt på grund af rekrutteringsudfordringer, lav. 


\section{Summary}

To ensure continued growth in Scandinavia, it is essential that companies can get the competencies they demand. Therefore, it is important to develop knowledge about whether companies' demand for labour is sufficiently covered by the supply of labour and whether there are mismatch problems on the Scandinavian labour markets.

The purpose of this study is to map the current differences and similarities in the recruitment challenges in a number of growth industries in Sweden, Denmark and Norway. Among the main questions which the report attempts to answer, are the questions about whether companies can get the necessary labour, the consequences of any recruitment challenges and how the companies try to meet these challenges.

The report focuses on five selected growth industries: Information and Communication Technology, Digital and Automated Production, Creative industry and Design, Green Technology and Life Science. These are industries where Scandinavian countries have traditionally done well in the global competition. Among other things, the industries are characterised by being specialised, having a position of strength in Scandinavia and a relatively high export trade. They are also industries which, to a great extent, depend on qualified labour.

The results in the report are based on a questionnaire survey in which 1,723 responses from companies in Sweden, Denmark and Norway were gathered. For the first time, a statistical analysis of on-line job advertisements is used to single out companies that have tried to recruit labour within the selected growth industries.

The study gives a lot of new insight into the extent of the recruitment challenges in Scandinavian countries and how the companies try to overcome these challenges in practice. The study generally indicates that the recruitment challenges and mismatch between supply and demand on the labour market are actual financial growth barriers in the five growth industries in the Scandinavian countries. The lack of labour has consequences for the companies for several reasons. In part, the study indicates that there is a production limitation because, in many cases, the companies need to postpone activities and, partly, that it can mean lower productivity as the companies need to recruit employees who do are not their first choice in terms of competence. 
The study shows that the recruitment challenges across the three countries are the biggest within the ICT and Digital and Automated Production industries where close on every third recruitment attempt is in vain. Here, the recruitment challenges and the derived production limitation are the biggest.

The study also indicates that the recruitment challenges are due to a mismatch in relation to the size of the labour supply (mismatch in terms of volume) and that the supply does not always have the right competencies (mismatch in terms of content). The companies have a number of solution initiatives in order to overcome these recruitment challenges of which increased international recruitment, including in the Scandinavian countries, and outsourcing are key elements. 


\section{Appendiks: Svarprocenter og frafald}

Spørgeskemaundersøgelsen blev gennemført elektronisk (via e-mail) i perioden fra uge 44 til uge 48 i 2016, og der blev udsendt to rykkere. Spørgeskemaundersøgelsen blev udsendt til i alt 5.848 virksomheder, og der er indsamlet 1.723 svar. Svarprocenten er således på $29 \%$

For hele stikprøven på 1.723 virksomheder er den maksimale usikkerhed (ved andele på $50 \%$ ) med go \% sandsynlighed på +/- 2 procentpoint.

I de enkelte lande og væksterhverv er vil den maksimale stikprøveusikkerhed i de fleste tilfælde være under 5 procentpoint, men kan være højere i enkelte celler (kombination af land og væksterhverv). I disse tilfælde er der gjort eksplicit opmærksomt på det i teksten.

Tabel 1: Antal respondenter og svar

\begin{tabular}{|c|c|c|c|c|c|c|c|c|}
\hline & \multicolumn{2}{|r|}{ DK } & \multicolumn{2}{|r|}{ NO } & \multicolumn{2}{|r|}{ SE } & \multicolumn{2}{|c|}{ I alt } \\
\hline & Svar & $\begin{array}{r}\text { Respon- } \\
\text { denter i alt }\end{array}$ & Svar & $\begin{array}{r}\text { Respon-den- } \\
\text { ter i alt }\end{array}$ & Svar & $\begin{array}{r}\text { Respon- } \\
\text { denter i alt }\end{array}$ & Svar & $\begin{array}{r}\text { Respon- } \\
\text { denter i alt }\end{array}$ \\
\hline Bio and medico & 236 & 447 & 218 & 485 & 78 & 450 & 532 & 1.382 \\
\hline Digital produktion & 163 & 454 & 98 & 541 & 78 & 437 & 339 & 1.432 \\
\hline IKT & 159 & 411 & 132 & 508 & 153 & 836 & 444 & 1.755 \\
\hline Kreativ og design & 168 & 495 & 132 & 528 & 108 & 565 & 408 & 1.588 \\
\hline I alt & 726 & 1.807 & 580 & 1.916 & 417 & 2.125 & 1.723 & 5.848 \\
\hline
\end{tabular}

Note Antallet af respondenter dækker over "aktive" respondenter, dvs. hvor den identificerede mail har være aktiv. Respondenter, hvor der er fx er fejl i mailadresse, medarbejderen er fratrådt stillingen eller lignende er frasorteret.

Kilde: Spørgeskemaundersøgelsen. 
Udover den statistiske usikkerhed er der risiko for skævhed i resultaterne som følge af systematisk frafald i besvarelserne.

Skævhed i resultaterne som følge af systematisk frafald er en grundlæggende udfordring ved spørgeskemaundersøgelser. Hvis der fx er tendens til, at virksomheder med rekrutteringsudfordringer i højere grad deltager end andre virksomheder, kan det trække i retning af at overvurdere niveauet af de afrapporterede rekrutterings-udfordringer. Men er bortfaldet jævnt fordelt mellem landene, vil det ikke påvirke de relative landesammenligninger.

Figur 17 viser svarprocenten og hermed også frafaldet (andelen, som ikke svarer) i de i alt 16 celler (kombinationen af tre lande og fire væksterhverv). Figuren viser, at inden for de enkelte lande fordeler svar og frafald sig nogenlunde ens på tværs af væksterhverv. Dette indikerer, at der ikke er større systematiske forskelle, som vil skævvride de relative sammenligninger.

Dog er der observeret en systematisk større andel svar inden for Life Science end for de andre kategorier. Denne tendens kan observeres i alle tre lande (dvs. ingen systematiske forskelle), og de relative sammenligninger vil kun i mindre grad være påvirket af forskellen.

Der er ikke identificeret større systematiske tendenser i frafaldet mellem lande, og frafaldet har således primært betydning for niveauet i de angivne andele, og i mindre grad for de relative sammenligninger på tværs af lande og væksterhverv. Risikoen for underliggende systematiske forskelle i frafaldet kan imidlertid ikke udelukkes. Dette kan fx omfatte skævheder i forhold til frafald fra forskellige virksomhedsstørrelser. 
Figur 17: Fordeling af svar og frafald

\section{Procent}

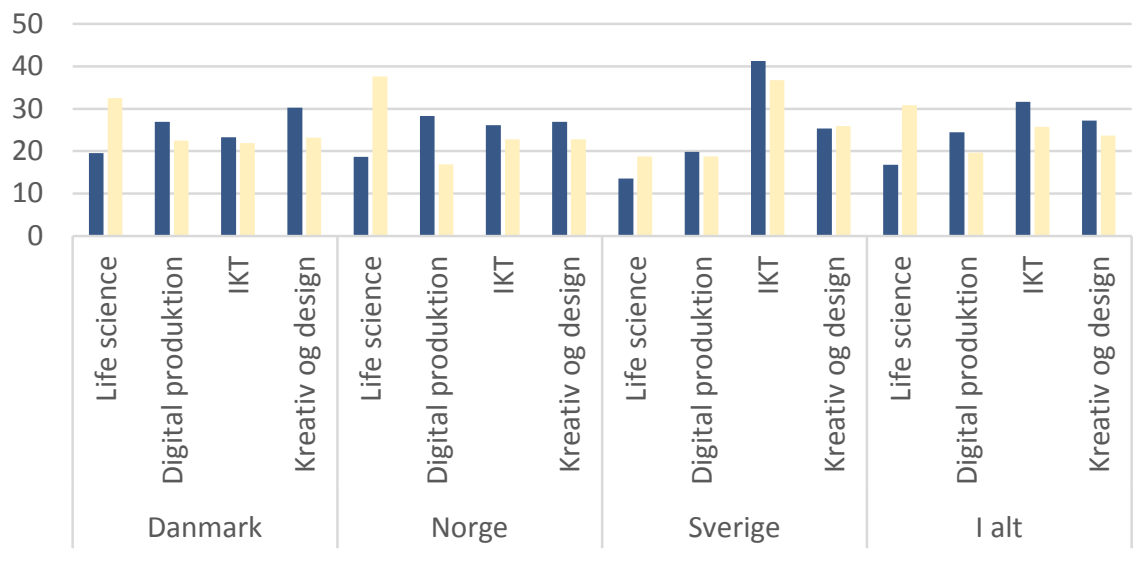

- Frafald Svar

Note: Søjlerne summer til $100 \%$ inden for hver af de tre lande og "i alt" for henholdsvis "frafald" og "svar"-kategorierne. Rensede svarprocenter, hvor ikke-aktive mail-adresser er frasorteret.

Kilde: Spørgeskemaundersøgelsen. 


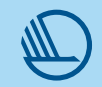

Nordisk Ministerråd

Ved Stranden 18

DK-1061 Copenhagen K

www.norden.org

\section{Mismatchproblemer i Norden}

Denne undersøgelse kortlægger de aktuelle forskelle og ligheder i rekrutteringsudfordringerne i en række væksterhverv i Sverige, Danmark og Norge. Resultaterne er baseret på en spørgeskemaundersøgelse blandt mere end 1.700 virksomheder. Undersøgelsen dokumenterer, at rekrutteringsudfordringer og mismatch mellem udbuddet af og efterspørgslen efter arbejdskraft er en reel økonomisk vækstbarriere i Norden. Undersøgelsen peger desuden på, at rekrutteringsudfordringerne på tværs af de tre lande er størst inden for erhvervene IKT og Digital og automatiseret produktion, hvor op mod hver tredje rekrutteringsforsøg er forgæves. Rekrutteringsudfordringerne skyldes, at arbejdsudbuddet både kan være for lavt og ikke altid har de rette kompetencer.

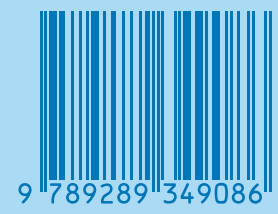

